\title{
Marquette University
}

\section{e-Publications@Marquette}

$1-1-2008$

\section{State and Local Anti-Predatory Lending Laws: The Effect of Legal Enforcement Mechanisms}

\author{
Raphael W. Bostic \\ University of Southern California \\ Kathleen C. Engel \\ Cleveland State University \\ Patricia A. McCoy \\ University of Connecticut - Hartford \\ Anthony Pennington-Cross \\ Marquette University, anthony.pennington-cross@marquette.edu \\ Susan M. Wachter \\ University of Pennsylvania
}

Accepted version. Journal of Economics and Business, Vol. 60, No. 1-2 (January/February 2008): 47-66. DOI.

NOTICE: this is the author's version of a work that was accepted for publication in Journal of Economics and Business. Changes resulting from the publishing process, such as peer review, editing, corrections, structural formatting, and other quality control mechanisms may not be reflected in this document. Changes may have been made to this work since it was submitted for publication. A definitive version was subsequently published in Journal of Economics and Business, VOL 60, ISSUE 1-2, (January/February 2008) DOI. 


\title{
State and Local Anti-Predatory Lending Laws: The Effect of Legal Enforcement Mechanisms
}

\author{
by \\ Raphael W. Bostic \\ School of Policy, Planning, and Development, University of Southern California \\ bostic@sppd.usc.edu \\ RGL 326, Los Angeles, CA 90089-0626. Tel.: +1 213 740-1220; fax: +1 213 740-6170. \\ Kathleen C. Engel \\ Cleveland-Marshall College of Law, Cleveland State University. Cleveland, OH 44115 \\ Kathleen.Engel@law.csuohio.edu \\ Patricia A. McCoy \\ School of Law, University of Connecticut, Hartford, CT 06105 \\ patricia.mccoy@law.uconn.edu \\ Anthony Pennington-Cross \\ Department of Finance, Marquette University, Milwaukee, WI 53233 \\ anthony.pennington-cross@marquette.edu \\ Susan M. Wachter \\ The Wharton School, University of Pennsylvania, Philadelphia, PA 19104 \\ wachter@wharton.upenn.edu
}

\section{Working paper version August 7, 2007}

Keywords: Subprime lending, enforcement mechanisms, anti-predatory lending laws, mortgage lending, homeownership

Running title: State and local anti-predatory lending laws 


\title{
State and Local Anti-Predatory Lending Laws: The Effect of Legal Enforcement Mechanisms
}

\begin{abstract}
Subprime mortgage lending has grown rapidly in recent years and with it, so have concerns about predatory lending. In response to evidence of predatory lending, most states have enacted new laws or expanded existing laws to address abuses in the subprime home loan market. The effect of these statutes is a matter of debate. This paper seeks to improve the understanding of this increasingly important issue and pays particular attention to the role that legal enforcement mechanisms play in this context. The results of the analysis are consistent with the view that anti-predatory lending laws influence subprime lending markets and that disaggregating the details of the overall legal framework into its component parts is essential for understanding subprime market dynamics. The restrictions, coverage, and enforcement components all have significant relationships with subprime market outcomes, with the coverage relationship found to be broadly consistent with the reverse lemons hypothesis put forward by Ho and Pennington-Cross (2007). The results also suggest that the newer mini-HOEPA laws have had an impact on the subprime market above and beyond the older preexisting laws, particularly for subprime originations. Broader coverage through these new laws is associated with higher origination likelihoods, while increased restrictions through the mini-HOEPA laws are associated with lower origination propensities.
\end{abstract}




\section{Introduction}

Subprime mortgage lending ${ }^{1}$ has grown rapidly in recent years ${ }^{2}$ and with it, so have concerns about predatory lending. ${ }^{3}$ By extending credit to borrowers who were historically excluded from the credit markets, subprime loans can be welfare enhancing; however, abusive subprime lending has the opposite effect and can actually reduce the welfare benefits that arise when borrowers have increased access to credit.

In response to evidence of predatory lending, most states and the federal government have enacted new laws or expanded existing laws to address abuses in the subprime home loan market. ${ }^{4}$ The federal law, the federal Home Ownership Equity Protection Act (HOEPA) was enacted in 1994. Since then, a growing number of states have enacted mini-HOEPA statutes to counteract predatory lending. Today, well over half the states have anti-predatory lending statutes of one kind or another. ${ }^{5}$ These laws vary in terms of the loans they cover, the practices they prohibit, and the methods of enforcement they permit. Other states have laws that regulate a more limited set of lending practices associated with predatory lending, such as prepayment penalties.

The effect of these statutes is a matter of debate. Critics charge that anti-predatory lending statutes reduce the availability of credit to borrowers who previously were creditconstrained, including lower-income households and people of color, by rationing credit and increasing the price of subprime loans. Supporters of these statutes argue that regulation is needed, both to allay consumer fears about dishonest lenders and to ensure that creditors internalize the cost of any negative externalities resulting from predatory loans. ${ }^{6}$ Concerns about these costs have increased recently with the rapid performance deterioration of subprime loans. ${ }^{7}$

The great variety of approaches taken by individual states to regulate lending -- in terms of the loans they cover, the restrictions they impose, and the enforcement mechanisms they establish -- permits the testing of the influence of various approaches on the flow and cost of credit. Prior studies of the impact of these laws have yielded mixed results. There are also questions about the accuracy of their findings and the generalizations that can be drawn from them. This paper seeks to address some of the weaknesses in these earlier studies in order to produce sharper results that improve the understanding of this increasingly important issue. In particular, this study considers a broader set of statutes than prior research, which allows for a more comprehensive, and more accurate, characterization of the legal environment. Moreover, this study takes into account enforcement mechanisms of anti-predatory lending laws that have not previously been examined in any detail, and thus broadens and deepens our understanding of the effects of government enforcement, private rights of action, and assignee liability provisions.

The basic hypothesis of this paper is that law design matters and that consumers and lenders may react in unanticipated ways. While laws can obviously decrease the demand and supply of subprime or high cost funds to homeowners and homebuyers, they can increase them as well. For example, from an institution's perspective, the introduction of 
a law can reduce legal uncertainty thereby making lending less risky and counteracting reductions associated with restrictions and legal enforcement mechanisms designed to reduce the flow of subprime credit. From the consumer perspective, as proposed by Ho \& Pennington-Cross (2007), some borrowers may be deterred because they fear being taken advantage of. This can work in a similar fashion as a lemons market. The introduction of a predatory lending law may reduce the fear of predation and actually stimulate demand for subprime lending.

The results of the analysis are consistent with the view that anti-predatory lending laws influence subprime lending markets and that disaggregating the details of the overall legal framework into its component parts is essential for understanding subprime market dynamics. The restrictions, coverage, and enforcement components all have significant relationships with subprime market outcomes, with the coverage relationship found to be broadly consistent with the reverse lemons hypothesis put forward by Ho and Pennington-Cross (2007). The results also suggest that the newer mini-HOEPA laws have had an impact on the subprime market above and beyond the older preexisting laws, particularly for subprime originations. Broader coverage through these new laws is associated with higher origination likelihoods, while increased restrictions through the new laws are associated with lower origination propensities.

This paper unfolds as follows. Part II provides a brief history of anti-predatory lending laws applying to residential mortgages. Part III reviews the empirical studies to date on the effect of state and local anti-predatory lending laws on residential mortgage credit. Part IV describes the dataset and the design of the study, and sets forth the results. Part V offers conclusions.

\section{A Brief Sketch Of Anti-Predatory Lending Laws}

Since ancient Babylonia, governments have sought to regulate abusive loans. In the United States, states have regulated interest rates on loans since the signing of the Constitution. ${ }^{8}$

Anti-predatory lending laws differ from traditional usury laws by focusing on practices and loan terms beyond interest rates. While many view state anti-predatory lending laws as a recent development, some states have regulated non-interest loan terms such as prepayment penalties and balloon clauses for decades. In some states, these restrictions are found in state usury statutes; in other states, they are found in local versions of the Uniform Consumer Commercial Code. ${ }^{9}$ Among jurisdictions with older laws, Alabama, Alaska, California, Connecticut, the District of Columbia, Hawaii, Idaho, Iowa, Michigan, Mississippi, New Mexico, North Carolina, Ohio, Oklahoma, Rhode Island, South Carolina, Utah, and Wyoming have individual restrictions on prepayment penalties; Maine restricts balloon clauses; and Maryland has restrictions on both.

In 1994, the U.S. Congress enacted the first modern, comprehensive anti-predatory lending statute, the Home Ownership and Equity Protection Act (HOEPA). HOEPA 
regulates only the costliest subprime loans, termed "high-cost loans," which are defined as loans exceeding one of the following two triggers:

- the annual percentage rate (APR) at consummation exceeds the yield on Treasury securities of comparable maturity plus eight percent for first-lien loans or ten percent for subordinate-lien loans; or

- the total points and fees exceed eight percent of the total loan amount or $\$ 400$ (subject to annual indexing), whichever is greater. ${ }^{10}$

HOEPA covers no more than five percent of subprime residential mortgages and likely less. ${ }^{11}$ For that narrow set of loans, HOEPA imposes a number of substantive restrictions on lending terms and practices, including limitations on balloon terms, negative amortization, advance payments, increased interest after default, rebates, prepayment penalties, due-on-demand clauses, payments to home improvement contractors, loans made without regard to ability to repay, and loan flipping. ${ }^{12}$ Lenders must also make specialized, advance disclosures to borrowers receiving HOEPA loans. HOEPA imposes liability for violations on lenders and assignees of HOEPA loans. ${ }^{13}$

In the late 1990s, many states also began adopting legislation to redress predatory lending. Some of these state laws were patterned on older laws that pre-dated HOEPA. For example, laws enacted during this time period by Colorado, Louisiana, Nebraska, and Vermont restricted prepayment penalties or balloon payments on some loans (Nebraska not terribly effectively) with low triggers or none at all. Vermont, Michigan, and Tennessee adopted new disclosure statutes. Other states, including New York and Massachusetts, initially addressed predatory lending through banking department regulations that authorized agency sanctions but not private lawsuits by aggrieved borrowers. Mississippi banned asset-based loans and capped fees to mortgage brokers. Kansas instituted additional loan restrictions, only some of which were subject to triggers, and indexed the triggers to interest rates on conventional mortgages, rather than on Treasury securities. Numerous states also adopted mortgage broker and banker licensing and regulation laws.

Starting in 1999, states began taking a different tack by enacting statutes patterned directly on HOEPA. North Carolina, the first state to adopt a true state "mini-HOEPA" law, passed its statute in 1999. The North Carolina statute took effect in two stages, with most restrictions becoming effective at stage 2. The statute is described in Table 1. Essentially, North Carolina used the same HOEPA APR trigger but a lower points and fee trigger and expanded HOEPA's substantive protections. In short order, the North Carolina's mini-HOEPA law inspired other states to enact mini-HOEPA laws of their own, which generally operate in addition to the other state laws mentioned above. As of January 1, 2007, twenty-nine states and the District of Columbus had mini-HOEPA statutes in effect (Table 2).

The state mini-HOEPA laws display considerable variation. With respect to coverage, some states, such as Connecticut, Florida, Kentucky, and Nevada, use the same 
numerical triggers as HOEPA. Most state mini-HOEPA laws, however, lower one or both of the HOEPA triggers. Restrictions also vary widely among the states, with some states imposing scant restrictions and others imposing heavier ones. Finally, the enforcement provisions in state mini-HOEPA laws vary considerably. Some laws only provide for government enforcement, while others afford injured borrowers the right to sue. Some laws authorize assignee liability, while others restrict private lawsuits to loan originators and assignees that do not qualify as holders-in-due course. Some laws authorize double or treble damages; others cap monetary relief in private lawsuits at compensatory damages only. ${ }^{14}$

Many of the states that adopted mini-HOEPA laws layered them on top of older restrictions on predatory lending that are still in effect. Eleven states augmented their old prepayment penalty laws with new mini-HOEPA laws; two more states grafted their mini-HOEPA laws onto older laws regulating other loan practices. Maryland's version of the layer-cake phenomenon is the most complex: its mini-HOEPA law stands side-byside with five older Maryland anti-predatory lending provisions. In all of these cases, the new mini-HOEPA statutes supplement, rather than supplant, the older state laws.

In sum, by January 1, 2007, only six states - Arizona, Delaware, Montana, North Dakota, Oregon, and South Dakota -- had no mini-HOEPA statutes or other older laws or regulations in effect restricting prepayment penalties, balloon clauses, or mandatory arbitration clauses in residential mortgages.

Federal law has preempted portions of these state laws at various times for certain types of lenders and loan products. The federal Alternative Mortgage Transactions Parity Act (AMTPA) preempts balloon clause restrictions for all mortgages by non-depository lenders except for traditional fixed-rate, fully amortizing mortgages. AMTPA applies to all states except states that opted out of its restrictions. ${ }^{15}$ The Home Owners' Loan Act preempts state anti-predatory lending laws for federal savings associations and their subsidiaries. ${ }^{16}$ Finally, effective February 12, 2004, the U.S. Office of the Comptroller of the Currency (O.C.C.) preempted state anti-predatory lending laws for national banks and their operating subsidiaries. ${ }^{17}$ Some states, such as Georgia, also have state "wild card" laws that waive their anti-predatory lending laws for state-chartered banks and thrifts and their subsidiaries to the same extent that federal preemption shields national banks and federal thrifts from those state laws. ${ }^{18}$

\section{Literature Review}

Although some states have regulated practices associated with predatory lending for decades, until recently there were no studies evaluating the effects of state and local antipredatory lending laws (other than caps on interest rates) on credit flows and loan prices. That changed with the passage of North Carolina's anti-predatory lending law in 1999. Since then, a number of studies have examined the effect of state mini-HOEPA laws on an assortment of outcomes. Many of these studies consist of event studies of one jurisdiction's law; others analyze outcomes nationally. 


\subsection{Event Studies Of Individual State Or Local Laws}

\subsubsection{The North Carolina Law}

The first studies looking at state and local anti-predatory lending laws consisted of event studies of the North Carolina law. Most of these studies examined the law's effect on the flow of credit. All agreed that subprime originations fell disproportionately in North Carolina after passage of the law, but there is sharp disagreement as to why. Other studies examined whether the dip in subprime loans in North Carolina after passage of its anti-predatory lending law was due to a reduction in supply or in demand. Finally, a pair of studies analyzed whether the North Carolina law targeted predatory loan terms without impairing legitimate credit.

Early studies of the North Carolina law used simple statistics to draw inferences. Ernst, Farris and Stein (2002) used Home Mortgage Disclosure Act (HMDA) data to compare subprime lending in North Carolina in 1999 and 2000 with subprime lending in the rest of the country. The authors found that total subprime originations fell in North Carolina in 2000, compared with other states. The study reported, however, that North Carolina had 15 percent more subprime home loans per capita than the national average in 2000 and that lower-income borrowers in North Carolina received a higher proportion of subprime to prime loans in 2000 than lower-income borrowers in any other state.

Another study focused on credit flows by surveying the rate sheets of several large subprime lenders who were active in North Carolina before and after enactment of the law (Inside B\&C Lending, 2001). The researchers found that the lenders offered a full menu of loan products with little or no effect on loan prices despite the changes in the law.

Elliehausen and Staten (2004) conducted a multivariate regression study to compare the volume of subprime mortgage originations in North Carolina with that in South Carolina, Tennessee, and Virginia before and after passage of the North Carolina law. The authors used a proprietary dataset with data on all closed-end subprime residential mortgages originated between June 1, 1997 and June 30, 2000 by nine major lenders who belonged to the American Financial Services Association. ${ }^{19}$ Although the dataset had loan-level credit (FICO) scores, the regression analysis did not use that data. Instead, the study controlled for borrower characteristics at the county level (including income, debt burdens, average house values, age cohorts, and length of delinquencies), plus the price of debt and passage of the North Carolina law. The study found that the volume of subprime mortgages originated in North Carolina counties dropped about 14 percent, relative to other counties in the control states, after passage of the state law. In relative terms post-law, subprime originations dropped for North Carolina borrowers with annual household incomes of $\$ 50,000$ or less, but rose for higher-income borrowers in that state.

There are several substantive issues with the Elliehausen and Staten study. First, a small number of lenders were surveyed. Second, the time-period examined ended before the law went fully into effect. ${ }^{20}$ Third, the model assumed that the control states had no 
anti-predatory lending provisions in effect. During all or part of the time-period studied, however, two of the control states - South Carolina and Virginia - had limits on prepayment penalties in residential mortgages. ${ }^{21}$ In addition, AMTPA preempted at least two of the North Carolina provisions that did go into effect during the time-period studied - the ban on balloon clauses in closed-end home loans and on prepayment penalties in personal home loans under $\$ 150,000$ - in all mortgages by non-depository lenders except for traditional fixed-rate, fully amortizing mortgages. Unlike North Carolina, however, South Carolina had opted out of AMTPA preemption. Thus, South Carolina was arguably more restrictive than North Carolina with respect to prepayment penalties during the time-period studied.

Two other studies looked at whether the reduction in North Carolina subprime loans post-law was due to supply-side or demand-side effects. A report by Burnett, Finkel and Kaul (2004), which used HMDA data and cross-tabulations, found that loan originations fell in North Carolina relative to South Carolina and Tennessee after passage of the law. The North Carolina decline was due to relative drops in application volumes; denial rates were lower in North Carolina than in the control states post-law. ${ }^{22}$

Similarly, using multivariate regression, Harvey and Nigro (2004) analyzed HMDA data before and after passage of the North Carolina law in July 1999 to determine the law's effect on home mortgage applications, originations, and denials. Georgia, South Carolina, Tennessee, and Virginia served as the control states. The authors treated all residential mortgage applications processed by lenders on the annual subprime lender list compiled by the Department of Housing and Urban Development (HUD) through 2000 as subprime loan applications. ${ }^{23}$

Harvey and Nigro found that the probability of subprime loan applications and originations fell in North Carolina post-passage, but the probability of subprime loan denials did not, relative to the control states. Thus, they attributed the falloff in North Carolina originations to reduced demand, not supply. Contrary to Elliehausen and Staten, they reported that the law had no differential effect on North Carolina borrowers with household incomes of $\$ 25,000$ or less. Similarly, subprime lending by bank lenders held steady in North Carolina following adoption of the law, while subprime lending by nonbank lenders fell there, in comparison with the control states. Finally, the market share of subprime loans fell in North Carolina after passage, compared with the control states. Similar to the Elliehausen-Staten study, the Harvey-Nigro study stopped before the North Carolina law took full effect, assumed that the control states did not regulate predatory lending in any way, and did not account for AMTPA preemption of parts of the North Carolina law.

A last group of studies examined whether the North Carolina law had struck a balance between curtailing abusive loans and ensuring the availability of credit to subprime borrowers. Ernst, Farris and Stein (2002) estimated that the North Carolina law saved North Carolina borrowers $\$ 100$ million by deterring predatory loan practices. Quercia, Stegman and Davis (2004) refined this analysis by using cross-tabulations on loan-level Loan Performance data of securitized subprime loans to determine whether the North 
Carolina law was well-tailored. The study improved upon its predecessors by comparing subprime lending patterns before initial implementation of the North Carolina law on October 1, 1999 and after full implementation on July 1, 2000. As did most of the other studies, Quercia et al. assumed that none of the southern control states had anti-predatory lending measures in place. The authors confirmed that overall subprime originations dropped in North Carolina following enactment, while subprime originations elsewhere increased. They found, however, that the North Carolina falloff was confined to the refinance market, where loan flipping abuses can occur. In contrast, subprime home purchase originations in that state grew as fast as or faster than in some nearby states and the U.S. generally. Almost ninety percent of the reduction in subprime mortgages in

North Carolina post-law consisted of subprime loans with at least one predatory feature. ${ }^{24}$ In the opinion of the authors, "the NC Act [was] doing what it [was] supposed to do." 25

\subsubsection{Other Studies Of Local Jurisdictions}

Two event studies considered the effect of state or local anti-predatory lending laws in jurisdictions other than North Carolina. Harvey (2003) studied HMDA data to ascertain the effect of anti-predatory lending ordinances adopted by Chicago and Philadelphia on subprime originations, applications, and denials. The Philadelphia ordinance was a local mini-HOEPA law; in contrast, the Chicago law barred the city from doing business with depositories or contractors who made high-cost loans that contained predatory terms. For Chicago, multivariate regression analysis showed that the likelihood of subprime loan denials and of nonbank originations of prime loans was no different in Chicago post-law than in the rest of Illinois. In contrast, after enactment of the ordinance, the likelihood of subprime originations generally and by nonbanks in particular was greater in Chicago than in the rest of Illinois. Among other things, this suggests that subprime lending migrated from banks to nonbanks after passage of the law. No conclusions can be drawn from the Philadelphia results because the study did not examine data during the brief time-period when the Philadelphia ordinance was in effect. $^{26}$

In an industry-commissioned study of the New Jersey law, DeMong (2004) surveyed 14 subprime lenders and 84 mortgage brokers in New Jersey. The respondents said that the dollar volume of subprime cash-out refinance loans unique to New Jersey dropped 57.7 percent between the two months immediately preceding the New Jersey law's implementation and the two months immediately afterward. Over the same time period, the respondents said that the dollar volume of subprime home improvement loans unique to New Jersey dropped 73.2 percent. The survey did not examine actual loan-level data or control for borrower characteristics or macroeconomic factors. ${ }^{27}$

\subsection{Nationwide Studies Of State Anti-Predatory Lending Laws}

With the growth in state mini-HOEPA laws, more recent studies have examined the effects of the state and local laws on a national scope. An early study by Morgan Stanley (2002), for example, surveyed subprime branch managers and mortgage brokers across the country. The investment bank reported that growth forecasts by respondents in 
"tough" states were not significantly different from growth forecasts by respondents in "easy" states. The report observed, "One of the consistent messages we heard from our respondents was that the increased level of disclosures was boosting consumer comfort levels with subprime products and thus providing a positive impact on loan volume." 28

Li and Ernst (2006) used the Loan Performance database of subprime securitized loans to analyze the effect of state laws from January 1998 through December 2004. The study ranked state laws according to the type of loans covered, points-and-fee triggers, substantive legal protections, and remedies available to borrowers. The authors concluded that state anti-predatory lending laws reduced the prevalence of predatory loan terms, without reducing subprime loan originations (except in Georgia and New Jersey), ${ }^{29}$ compared with unregulated states. In addition, nominal interest rates on mortgages stayed level or dropped in all states with anti-predatory lending laws except Georgia and Virginia, ${ }^{30}$ compared with the controls.

Using HMDA data, Ho and Pennington-Cross (2006b) constructed a legal index to examine the effect of state anti-predatory lending laws on the probability of subprime applications, originations, and rejections. They focused on border counties of adjacent states with and without anti-predatory lending laws, rather than entire states, to help hold labor and housing markets constant. ${ }^{31}$ Having a state anti-predatory lending law had no effect on the probability of origination and only a scant negative effect on the probability of applications, while it reduced the likelihood of being rejected. Stronger restrictions reduced the likelihood of origination and applications, but had no effect on the likelihood of rejection. Conversely, stronger coverage increased the likelihood of origination and applications without affecting the likelihood of rejection, suggesting that anti-predatory lending laws with lower triggers boost demand by reducing consumer fears about abusive lenders.

Ho and Pennington-Cross (2006a) used the same legal index and border area methodology to examine the effect of state anti-predatory lending laws on the cost of credit. Using HMDA data from 2004, they discovered that subprime loans originated in locations with anti-predatory lending laws had lower APRs than loans in unregulated states. They also found that increasing the strength of a law had the same effect. In both cases, greater coverage rather than stronger loan restrictions explained the lower APRs in regulated states. A comparable analysis using Loan Performance data from 1998 through 2005 yielded somewhat different results. State anti-predatory lending laws modestly increased nominal interest rates on fixed-rate loans, but lowered them on adjustable-rate loans. For both types of loans, laws with more restrictions displayed the same or higher spreads, while laws with greater coverage displayed lower spreads.

A national study by Elliehausen, Staten and Steinbuks (2006) used a proprietary database of subprime loans originated by eight large lenders from 1999 through 2004 , covering about 22 percent of high-priced residential mortgages. The dataset contained loan-level information on APRs and points and fees, which helped the authors to distinguish loans covered by state mini-HOEPA laws from loans that were not. Approximately 80 to 90 percent of the mortgages in the database were refinance loans. 
The study used three approaches to examine the effect of state laws on subprime originations. In the first approach, the authors modeled the presence or absence of a state law as a binary variable and found that the presence of a law was associated with a decrease in total subprime mortgages, including both the high-cost and non-high-cost variety. The second approach ran the same analysis with the combined legal index developed by Ho and Pennington-Cross and reached the same result. The third approach consisted of an event study that used pre-law observations to predict the number of expected subprime originations for the post-law period. The state-by-state results were randomly distributed. Six of the states with strong laws (by our estimation) ${ }^{32}$ had weaker-than-expected originations and the other five had originations that were strongerthan-expected or level. The authors interpreted these findings as evidence that lenders shifted lending from covered high-cost loans to uncovered loans in response to the enactment of state mini-HOEPA statutes. It is not clear from the study, however, what role coverage played versus restrictions. Similarly, it is not clear whether any decrease in originations was due to a reduction in demand, in supply, or in both.

\section{Taking A Deeper Dive: Our Study Of The Impact Of State Anti-Predatory Lending Laws}

This study builds on the prior literature by conducting a national examination of the impact of all anti-predatory lending laws, not just mini-HOEPA laws, on subprime mortgage markets. Following Harvey and Nigro (2004) and Ho and Pennington-Cross (2006), and given our interest in the effects of these laws on both applicants and lenders, we focus on three outcomes - (1) the probability of applying for a subprime loan relative to a prime loan, (2) the probability of originating a subprime loan relative to a prime loan, and (3) the probability of a subprime application being rejected. We relate these outcomes to various borrower and locational characteristics as well as to the antipredatory law environment in which the borrower and lender made their decisions for calendar years 2004 and 2005.

Our study distinguishes itself from its predecessors in several respects. Most significantly, it reflects a new and more comprehensive canvassing of primary legal sources to paint a complete picture of the landscape regarding anti-predatory lending laws. This new collection effort has highlighted 16 additional states that have antipredatory lending laws that were not identified in prior studies that used surveys of state laws compiled by law firms or trade associations. ${ }^{33}$ Thus our study considers 41 states (including Washington DC) while others considered at most 25. In addition, we study the incremental effect of layering a modern mini-HOEPA law on top of an older-style law that addresses only one or a few loan terms.

This new collection effort allows this study to make two advances. First, it permits one to distinguish between the older laws and the new mini-HOEPA laws in terms of incidence and effect. The data can be partitioned such that we can characterize states according to the independent presence of older style and newer mini-HOEPA laws. This permits the creation of two separate indexes and the determination of whether the mini- 
HOEPA laws had an effect above and beyond the older laws already on the books in many states.

Second, this new collection effort has resulted in a dataset that permits an examination of the effects of various enforcement mechanisms established by the laws, which was previously not possible. We therefore are able to assess whether legal enforcement mechanisms matter for individual and lender behavior. Among other things, the new data allow us to control for the presence and strength of assignee liability provisions in state anti-predatory lending laws, which is critical because over eighty percent of subprime home mortgages have been securitized in recent years. ${ }^{34}$ Assignee liability laws are ones that allow borrowers to sue (or at least raise defenses against) investors who have bought their loans.

In other respects, this research builds upon prior studies. Like other projects, we use HMDA data, which provides the broadest coverage and enables us to examine most residential mortgage lending nationwide. The advent of HMDA pricing data in 2004 permits us to distinguish prime from subprime loans with greater accuracy than studies using HMDA data for years before 2004. We thus limit our focus to 2004 and 2005 to capitalize on this enhanced measure.

We use two methods to identify subprime loans. First, as in the prior literature, we use a list of subprime lenders generated by HUD through industry trade publications, HMDA data analysis, and phone calls to confirm the extent of subprime lending. ${ }^{35}$ Second, we define loans reported by HMDA as having an APR/comparable Treasury yield spread of 3 percentage points (300 basis points) or higher as being subprime loans. Unfortunately, the spread is only reported on originated loans so we cannot directly examine the demand for loans through the application function. For observations in 2004, all empirical tests are repeated using either the HUD list definition for subprime loans (denoted as "List" in the tables) or the HMDA pricing rule to define subprime loans (denoted as "Price" in the tables). For loans originated in 2005, the HUD list was not yet available, so we report results only for originations, using the HMDA pricing rule alone.

While we model the presence of a law as a binary variable, as do other studies, we also consider how the strength, coverage, and enforcement mechanisms of state antipredatory lending laws influence market outcomes. In addition, because the treatment of effective dates has been an issue in earlier studies, we establish an explicit approach that excludes any jurisdiction whose mortgage lending laws changed in any material respect during the calendar year. Finally, we control for borrower and location characteristics such as unemployment rates, housing vacancies, population growth, and income.

The following subsections provide more detail regarding our empirical work. Because of its importance for the current study, the data collection effort and the creation of our new index for state-level anti-predatory lending laws is discussed in detail below. We then discuss the identification strategy for determining the effect of anti-predatory lending laws. Following this is a discussion of the empirical model and then the empirical results. 


\subsection{Description Of The Data}

\subsubsection{Legal Dataset And Index}

We created a legal index that refines and builds on an index previously created by Ho and Pennington-Cross (2006a). The Ho and Pennington-Cross index coded state and municipal laws along two dimensions: coverage and restrictions, each of which contained four measures. In creating their index, Ho and Pennington-Cross relied on a chart of antipredatory lending laws produced by a private law firm.

Like Ho and Pennington-Cross, our legal index contains four coverage and four restriction measures. Our study differs, however, in several respects. First, we analyzed the actual statutes governing lending in every state to identify anti-predatory lending provisions and did not limit ourselves to mini-HOEPA laws. Second, our index includes a third dimension - enforcement - that has two components: assignee liability and enforcement methods against originators. Lastly, through our legal expertise, we were able to detect subtleties in the laws that led to a more refined index and more accurate coding of the laws. Table 3 fully describes the parameters of the index.

In measuring the breadth of a law's coverage, we take into account the types of loans that are covered by the law and any annual percentage rate (APR) and points and fee thresholds that trigger application of the law. Laws that are HOEPA-equivalents in terms of coverage are scored 0 . Laws that govern all loans or that have no triggers receive the highest scores on the index.

The first measure in the coverage index is the type of loan covered by the law. Laws that apply to more loan types receive a higher score. For example, if a law does not cover Federal Housing Administration or Veteran's Administration loans, it is scored 1. In contrast, laws that apply to all types of loans receive a score of 4 . The APR and points and fees measures are graduated with HOEPA serving as the floor. Thus, HOEPA equivalents are scored 0 and laws without triggers receive the highest possible scores. Those laws with triggers lower than HOEPA's are assigned intermediate scores based on where they fall relative to HOEPA.

The restrictions measure considers four features of anti-predatory lending laws: limits on prepayment penalties, restrictions on balloon payments, requirements for credit counseling or notice of the availability of such counseling, and restrictions on loan terms that limit or bar borrowers' access to the courts. As with the coverage measures, the laws that impose the strongest restrictions receive the highest number of points on the restrictions index. A ban, for example, on prepayment penalties would code a 4 while a law that was silent on prepayment penalties would be a 0 , with gradations between based on the timing of bans on prepayment penalties. A similar scale holds for limits on balloon payments. 
Laws that require borrowers to obtain credit counseling before closing on their loans are assigned the highest number, which is 2 for this measure. Those laws that only recommend counseling or that only require that borrowers be given notice of the right to or the value of credit counseling receive a 1, whereas laws that neither recommend nor require counseling are assigned a 0 . Some jurisdictions prohibit loan terms that require borrowers to submit any disputes arising from their loans to arbitration or that otherwise restrict borrowers' access to the courts. Using a scale of 0 to 2, laws that prohibit such terms are scored a 2. Laws with partial restrictions are scored 1. And, laws without any restrictions are assigned a score of 0 .

The enforcement mechanisms component of the index contains two measures: assignee liability and enforcement against originators. The former measures the potential liability that purchasers or other assignees of mortgages have for wrongdoing by originators. This measure is important because there has been concern that assignee liability provisions in state laws could impede the availability of credit or drive up the price of loans. Our assignee liability measure assigns a 0 to laws that do not contemplate assignee liability unless the assignee had notice of the violation of the law before or at the time of the assignment or participated in the violation of the law. Laws that allow borrowers to raise defenses, including claims of recoupment, to foreclosure or collection actions brought by assignees receive a 1. Stronger laws that impose liability on assignees who fail to engage in due diligence designed to identify loans that contain predatory features are assigned a 2. Laws that allow for limited claims against assignees even if they engage in due diligence are scored a 3. This score also applies if assignees are liable for willful violations by originators. The highest score is reserved for laws that impose liability on assignees without providing any due diligence safe harbors.

The final measure takes into account the variation in enforcement schemes and available remedies against originators. Laws that can only be enforced by state government, i.e., that preclude private lawsuits, are given the lowest score. Those laws that allow private lawsuits for compensatory damages, but no punitive relief are scored a 1 and those that allow private lawsuits with punitive relief are assigned a 2 .

\subsubsection{Creating State Level Law Indexes}

State level law indexes were constructed using the component scoring system just described. Similar to Ho and Pennington-Cross (2006b) each of the components is rescaled to insure that the indexes are not overly representative in terms of absolute value or variance of any single subcomponent. For illustration, consider the law in Alabama and the coverage subcomponents (loan purpose, APR trigger 1st Lien, APR trigger higher liens, and points and fees trigger). Alabama does not have a mini-HOEPA law but does have an older law regulating subprime lending. First, each subcomponent is divided by the maximum possible value, so that values will range from 0 to 1 . Alabama's score for loan purpose was a 2, while the maximum allowable loan purpose score is 4 . Therefore, Alabama's re-scaled loan purpose value is 0.5 . The same procedure is used for the remaining subcomponents (APR trigger 1 st Lien $=1$, APR trigger higher liens $=1$, and

points and fees trigger $=1$ ). The sum of these values equals 3.5 for Alabama. This 
process is repeated for all laws. Alabama's coverage value is then divided by the average coverage value for all states (2.068627). As a result, Alabama's coverage index value is 1.69 (3.5/ (2.068627). This approach is applied to each of the dimensions that make up the coverage, restrictions and enforcement mechanisms indexes. As a result the average value of each of the indexes is 1 .

Lacking a generally accepted method for generating an index of this sort using the three component values, we build additive and multiplicative indexes to evaluate whether index construction drives results and, if so, how. The additive version takes the value of each of the components and adds them together (index ${ }^{\mathrm{A}}$ ). An additional question is whether the interaction of the components is important, which is less easily to establish using an additive index. To explore this and obtain a better sense of the contingent nature of the components (for example, restrictions should only matter if they cover some of the market) a multiplicative index is also created. This index takes each of the components and multiplies them together $\left(\right.$ index $\left.^{\mathrm{M}}\right) .{ }^{36}$

Separate indexes are created for the "new" mini-HOEPA laws and the older preexisting laws. In general, the older laws were in effect prior to the first mini-HOEPA law, North Carolina, and did not follow the HOEPA structure. Both indexes are created using the component scoring methodology and then added together to calculate a combined index.

Tables 4, 5 and 6 provide the indexes for each of the 50 states and the District of Colmbia for the mini-HOEPA laws, the preexisting laws, and combined compilation. There is substantial variation in the laws across all components, but in general, it appears that laws with strong market coverage tend to have stronger restrictions and enforcement mechanisms (coverage, restrictions, and enforcement mechanisms are all positively correlated). In addition, the mini-HOEPA and preexisting law components are only very weakly correlated (less than 10 percent) with each other in no obviously discernable fashion.

\subsection{Identification Strategy}

To identify the impact of anti-predatory lending laws on the subprime market, most of the literature uses state-level analyses, in either an event study or panel data framework, that focus on an indicator variable signifying whether a law is in effect. However, by including all loans in the state this approach implicitly assumes that loans made on opposite ends of a state are similar and that all parts of the state are experiencing similar economic conditions. These assumptions are very unlikely to hold and are especially problematic when using data sets with missing information (Elliehausen and Staten, 2004 \& 2006; Harvey and Nigro, 2003 \& 2004; Li and Ernst, 2006).

We use a different geographic sampling approach that focuses on lending activity along state borders. Loans are included in the sample if they originate in a county that is geographically along a state border, if at least one of the two border states (the county's state and the neighboring state) has an anti-predatory lending law. However, if the status 
of anti-predatory lending laws in either state changes during the calendar year (e.g., new laws become effective or old ones are amended), the loans are excluded from the sample for that year. ${ }^{37}$

This approach takes advantage of the non-economic nature of state boundaries. Because economic forces are typically quite similar in such neighboring counties, border pairs reflect a strong natural experiment which makes differences in the legal framework a focal point. This recognition has made the border pair geographic sampling approach a standard in academic research on the effects of laws. As examples, it has been used by Holmes (1998) to establish the relationship between right-to-work laws and employment, Pence (2006) to study the impact of foreclosure laws on mortgage markets, and Ho and Pennington-Cross (2006) to examine the effect of lending laws on mortgage markets.

Table 7 describes the geographic distribution of loan originations along state borders. Each of these border pairs will effectively define a region through fixed effects (dummy variables). Any remaining differences will be associated with control variables describing the borrower or applicant and the location of the property at the county and tract level. This approach is best described as a differences-in-differences identification approach, which is augmented through a geographic-based sampling approach.

The base model can thus be specified as:

Outcome $_{i t}=\beta_{0}+\beta_{1}$ Law $_{i}+\sum_{j=A L F L}^{V A W V} \beta_{2 j}$ Border $_{j i}+\beta_{3}$ Borrower $_{i}+\beta_{4}$ Location $_{i}+\beta_{5}$ OCC $_{i}+\varepsilon_{i}$

where $\mathrm{i}$ and $\mathrm{j}$ index, respectively, the individual loans and the state border pair, Law indicates whether the state where the loan originates has an anti-predatory lending law or laws and the strength of the law(s) across various dimensions, ${ }^{38}$ Border indicates that loans are in border counties for the indicated pair of states (North Carolina and Virginia, NCVA, being the excluded state border pair), Borrower represents borrower characteristics, Location represents location specific characteristics, $O C C$ identifies whether the lender was regulated by the U.S. Office of the Comptroller of the Currency (OCC), and $\varepsilon$ represents an identically and independently distributed random error term. ${ }^{39}$ Because the outcomes are binary, we estimate all relationships using the logit specification. $^{40}$

In the base model the vector Law only includes the variable Ineffect which indicates that the loan is in a state where an anti-predatory lending law is effective. Ho \& Pennington-Cross (2006b) and Li and Ernst (2006) show that such laws can have either positive or negative impacts on the volume of subprime lending but tend to depress rejection rates on average. Therefore, the sign of the coefficient on Ineffect is largely indeterminate. In alternative model specifications, Law includes (1) the full index or (2) the coverage, restrictions, and enforcement mechanisms indexes. The full index is not expected to have much impact on the subprime mortgage market, because restrictions may depress the market by limiting the availability of some loan types, while coverage may stimulate demand in the market by making potential customers less fearful of 
predation. There is no prior evidence on the impact of enforcement mechanisms on the subprime mortgage market, but they may stimulate the market if potential customers are convinced that the law will eliminate any predation or depress the market if compliance is difficult or expensive.

Since the border dummies control for the economic conditions along the border of geographically contiguous states, the sign of the coefficients could be positive or negative depending on local economic conditions.

Table 8 includes variable descriptions and the source for the borrower and location controls. We expect that borrowers will be more likely to use subprime loans in locations with depressed economic conditions, in areas with a high percentage of minority households, and when applicants have low income or are requesting large loan amounts relative to income (Calem, Gillen, and Wachter, 2004; Pennington-Cross, 2002). The county housing vacancy rate, unemployment rate, and population growth over the prior year are included as proxies for location characteristics. Borrower income, the loan-toincome ratio, and the census tract's minority percentage are also included as proxies for borrower traits. Unfortunately, borrower credit score data are not publicly available despite the fact that credit score is an important factor in underwriting both prime and subprime loans.

Table 9 provides summary statistics for the estimation data set. For each of the potential outcomes, 200,000 loans are randomly sampled from the appropriate border counties for estimation to reduce estimation time. The 2004 data indicate that 16 to 18 percent of loan originations are classified as subprime, 33 percent of applications are subprime, and 44 percent of subprime applications are rejected. In addition, subprime borrowers tend to have substantially lower incomes, request higher loan-to-income ratios, and live in locations with more minorities, higher vacancy rates, higher unemployment rates, and lower density. The 2005 data show a substantially higher fraction of subprime loans than in 2004 ( 27 percent versus 16 percent). There are many small changes in the magnitude of all variables when comparing 2004 to 2005, but the summary statistics are very similar and these differences can reflect changes in the economic environment as well as the different composition of the sample.

The last variable included is an indicator that the lender was regulated by the OCC. The OCC is the regulator of national banks and has exempted national banks from state and local anti-predatory lending laws. Therefore, law impacts may differ for national banks, as identified by the OCC dummy variable.

\subsection{Logit Results}

Tables 10 and 11 provide the coefficient estimates, the standard errors, and the odds ratios for the location and borrower controls and the Ineffect dummy variable. Table 10 provides results for the origination outcome and Table 11 provides results for the application and rejection outcomes. 
Law Variables -- The impact of the average law can be seen in Tables 10 and 11 by examining the coefficient and associated odds ratio for the Ineffect variable. The typical law appears to have no measurable impact on the odds of applying for or entering into a subprime loan. In addition, the typical law tends to reduce the odds of being rejected on a subprime application by 7 percent. In summary, the typical law has very little impact on the subprime mortgage market in terms of overall credit flows.

A similar result is found when one uses the multiplicative in place of the additive index (results not shown). Most coefficients on this index were not significant and were of very small magnitudes when they were. In short, the results here reinforce the previous finding and corroborate the results in Ho and Pennington-Cross (2006b) and Li and Ernst (2007) showing that the existence of a law has a very small impact on the flow of subprime credit.

However, our hypothesis that the particulars of the legal framework are important suggests that further investigation is warranted. Table 12 reports results from a series of specification tests that aim to establish the accuracy of our conjecture. Panel A reports results for 2004 originations using the HUD list definition of subprime lending, panel B for 2004 originations using the HMDA price definition, panel C for 2005 originations using HMDA price definition, panel D for 2004 applications using the HUD list definition, and panel E for 2004 rejections using the HUD list definition.

Each panel of the table reports the results for 5 alternative specifications, which the following discussion will draw on. The first two specifications distinguish between the effects of older preexisting laws and newer mini-HOEPA laws. The results here lend some weak support to the view that both sets of laws had an impact on subprime mortgage markets. The existence of the older type of law on a state's books is associated with an increased probability of a subprime loan being originated in some cases and not in others. Similarly, results are mixed for the new laws, indicating that the laws had no effect on or led to a slight decline in the probability of subprime origination. In all cases with significant coefficients, however, the magnitude of the effect is found to be quite small. Furthermore, the similarity of results using the additive and multiplicative indexes suggests that the method of index construction is not driving the findings.

Of course, the aggregated index is a blunt measure. Two anti-predatory lending laws can have the same full index but actually be very different, depending on the relative strength of the three index components. These variations can result in substantially different market responses. As a result, we can gain more meaningful insights by analyzing the effect of each component of the index. Specifications 3 and 4 in Table 12 decompose the indexes into their components to test for these different impacts.

Specification 3 shows the impact of the combined regulatory forces associated with the older laws and the more recent mini-HOEPA laws. The results show that disaggregating the laws into their component parts is important. For example, using the HUD list definition of subprime, the results for 2004 originations indicate that both restrictions and coverage rules have effects, and that these serve to negate each other. An 
increase in the restrictions component by one standard deviation (2.29 units) decreases the odds of originating a subprime loan by 9 percent, while an increase in the coverage component by one standard deviation ( 2.5 units) increases the odds of originating a subprime loan by 11 percent. Similar findings for combined restrictions and coverage are observed in 2005 using the HMDA price definition of subprime.

The results for 2004 originations using the HMDA price definition of subprime (panel B) differ from those in 2004 using the HUD list definition or those in 2005 using the HMDA price definition. However, there are reasons to discount the 2004 HMDA price findings. Avery, et. al (2006) provide evidence suggesting that many subprime loans were not identified as such in the 2004 because of yield curve dynamics. As a result, the data are biased such that those subprime loans with lower APRs are omitted. Another consequence is that many loans originated by specialized subprime lenders are not reported as such in the 2004 HMDA pricing data. For example, Aames Funding Corporation reported that 55 percent of their loans were subprime in 2004 but 90 percent where subprime in 2005 . This pattern repeats among many subprime specialists. In addition, because 2004 was the first year institutions were required to report pricing information, errors in reporting are likely. Indeed, the Federal Financial Institutions Examination Council issued guidance alerting HMDA reporters of potential problems after an initial review of submissions. ${ }^{41}$

The origination results for enforcement are weaker than those for restrictions or coverage. No relationship is observed between originations and enforcement in 2004 using either definition, but we do observe an elevated probability of subprime originations in states with stronger enforcement in 2005. The stronger enforcement schemes include private rights of action and assignee liability.

Components are also significantly associated with applications (panel D) and rejections (panel E). In contrast to findings in Ho and Pennington-Cross (2006), here the coverage component is negatively associated with applications. All the components have a significant relationship with rejections. Applicants in states with stronger restrictions are more likely to have their applications rejected. However, greater coverage and more stringent enforcement are associated with fewer rejections of subprime mortgage applications.

The fourth specification in the table decomposes these variables further by separately analyzing the components of mini-HOEPA laws and the older laws that govern only one or a few loan terms. For originations, the evidence suggests that the newer mini-HOEPA laws have a greater effect than the older laws. These effects have the same offsetting pattern we observed for the aggregated component indexes. New restrictions on practices are significantly associated with a decreased likelihood of a subprime loan being originated, while new laws featuring expanded coverage tend to increase the probability of a loan being originated.

For applications and rejections, the story is a bit different in that both the older and newer laws appear to play a role in subprime market outcomes. Both sets of laws are 
significantly associated with both applications and rejections and the component effects for both sets of laws are often quite similar. Expanded coverage is associated with reduced probabilities of both and restrictions are associated with higher probabilities of both (weakly for applications). Interestingly, new increased enforcement is significantly associated with decreased likelihoods of subprime application and rejection.

Control Variables -- The results for the probability of origination are very consistent across different years and using different definitions of subprime. For example, the odds ratio for income range from 0.92 to 0.95 and the coefficient estimate is significant in all three regressions. Similarly consistent results are found for the minority, unemployment, and $O C C$ variables. In addition, the loan2income variable always reduces the odds of originating a subprime loan, and more densely populated areas are always associated with a lower probability of originating a subprime loan. Put simply, a subprime origination is most likely in locations with high percentages of minority residents and people on low incomes, and with high rates of unemployment in both 2004 and 2005.

In terms of applications, borrowers in locations with a concentration of minority households tend to apply for subprime loans much more often (odds ratio $=3.61$ ) as well as households with lower incomes (odds ratio $=0.95$ ) and higher unemployment rates (odds ratio $=1.04$ ). The probability of being rejected on a subprime application also meets expectations. For example, lower incomes, higher unemployment rates, and living in a predominantly minority area all increase the odds of having a subprime application rejected.

\section{Discussion and Conclusion}

The current research builds upon prior research examining the effects of antipredatory lending laws on subprime lending markets. It uses a new, improved data set that better describes the legal landscape regarding predatory lending. This new data permit a broader coverage of states, an assessment of whether effects differ according to whether a law was an older preexisting statute or a newer mini-HOEPA law, and the evaluation of the effects of remedies against originators and assignee liability.

Our results are consistent with the view that anti-predatory lending laws influence subprime lending markets. The analysis indicates that the presence of state-level laws that regulate subprime lending, when considered in the aggregate, appear to have little impact on subprime originations, applications or rejections. However, the empirics also show that disaggregating the details of the overall legal framework into its component parts is important for understanding subprime market dynamics. The results for the restrictions component are consistent with expectations and the prior literature. More restrictive state laws reduce subprime originations and increase subprime rejection likelihoods. Regarding coverage, although laws with broader coverage are associated with reduced subprime application propensities, they are also associated with lower subprime rejection rates. On balance, the reduction in rejection propensity appears to outweigh the application effect, as we observe higher subprime origination propensities in states with broader coverage. Finally, variation in enforcement provisions is not 
associated with subprime origination or application likelihoods, but we do observe a significant reduction in rejection probabilities as enforcement methods strengthen.

In terms of other implications of the research, the component analysis suggests that the lack of an overall relationship is explained by the opposing restrictions and coverage effects. In short, the evidence here argues strongly that the design of the legal framework is important for market outsomes. The results also suggest that the newer mini-HOEPA laws have had a impact on the subprime market above and beyond the older preexisting laws, particularly for subprime originations. Finally, the evidence that laws with broader coverage lead to an increased probability of applications is broadly consistent with the reverse lemons hypothesis put forward by Ho and Pennington-Cross (2007). This theory argues that a legal framework provides a protection to borrowers that induces creditworthy applicants who had opted out of the market to apply for loans.

The results also point to the need for additional research. Questions remain as to the how the interaction of the various legal framework components shape subprime market outcomes. For example, restrictions and enforcement might be mutually reinforcing or one might negate the effect of the other. Additional research might focus on how credit quality drives observed relationships, particularly in the context of subprime underwriting and rejection rates. Finally, the analysis indicated that OCC activity influences subprime market outcomes. Future research might explore this further, particularly given the issue of OCC preemption. The differing levels of regulations for institutions could conceivably affect the distribution of applications and originations.

Acknowledgements:

The authors would like to thank Bryan Lincoln, Peter Siegelman, conference participants, and an anonymous reviewer for their comments on an earlier draft and Eric Holtz and Kevin Schwin for their valuable research assistance. 


\section{Bibliography}

Apgar, W. C. and Duda, M. (May 11, 2005.) Collateral damage: The municipal impact of today's mortgage foreclosure boom. www.hpfonline.org/profile/ApgarDuda\%20Study\%20Final.pdf.

Azmy, B. (2005.) Squaring the predatory lending circle: A case for states as laboratories of experimentation. Florida Law Review 57(2): 295-410.

Avery, R. B., Brevoort, K. P. and Canner, G. B. (2006.) Higher-priced home lending and the 2005 HMDA data. Federal Reserve Bulletin: A123-A166.

Board of Governors of the Federal Reserve System (December 20, 2001.) Truth in Lending. 66 Fed. Reg. 65,604.

Board of Governors of the Federal Reserve System (December 10, 2004.) HMDA Data Collection and Reporting. Memorandum to officers and managers in charge of consumer affairs sections.

http://www.federalreserve.gov/boarddocs/caletters/2004/0411/caltr0411.htm

Burnett, K., Finkel M., and Kaul, B. (September 14, 2004.) Mortgage lending in North Carolina after the anti-predatory lending law.

http://www.namb.org/images/namb/documents/PDF/2004_10_15_mba_nc.pdf.

Calem, P., Gillen., K. and Wachter S. (2004.) The neighborhood distribution of subprime mortgage lending. Journal of Real Estate Finance and Economics 29(4): 393-410.

Center for Responsible Lending (September 16, 2004.) Comment on MBA study and press research on North Carolina predatory lending law, CRL Issue Paper 8 http://www.responsiblelending.org/pdfs/mbacomments-long.pdf.

Center for Statistical Research (February 2003.) Shrinking the pie: Projecting the impact AB 75 will have on New Jersey borrowers. working paper http://www.afsaonline.org/CMS/fileREPOSITORY/AB\%2075\%20and\%20its\%20Impact $\% 20$ on\%20New\%20Jersey\%20Borrowers.pdf.

DeMong, R. F. (March 26, 2004.) The impact of the New Jersey Home Ownership Security Act of 2002. working paper http://www.namb.org/images/namb/documents/PDF/2004_03_26_nj_results.pdf.

Demyanyk, Y. (October 2006.) Income inequality: Time for predatory lending laws? The Regional Economist, Federal Reserve Bank of St. Louis

http://stlouisfed.org/publications/re/2006/d/pages/income_inequality.html.

Duncan, D. (2006.) Fourth general session: Economic/Housing outlook. PowerPoint slides. 
http://www.mortgagebankers.org/files/Conferences/2006/93rdAnnualConvention/MBA_ DougDuncan4thGeneralSession_final.pdf.

Elliehausen, G. and Staten, M. E. (2004.) Regulation of subprime mortgage products: An analysis of North Carolina's predatory lending law. Journal of Real Estate Finance and Economics 29(4): 411-434.

Elliehausen, G., Staten, M. E. and Steinbuks, J. (March 2006.) The effects of state predatory lending laws on the availability of subprime mortgage credit. Credit Research Center Monograph \#38 http://www.business.gwu.edu/research/centers/fsrp/pdf/M38.pdf.

Engel, K. C. (2006.) Do cities have standing? Redressing the externalities of predatory lending. Connecticut Law Review 38(3): 355-391.

Engel, K. C. and McCoy, P. A. (2007.) Turning a blind eye: Wall Street finance of predatory lending. Fordham Law Review 75(4): 2039-2103.

Ernst, K., Farris, J. and Stein, E. (August 13, 2002.) North Carolina's subprime home loan market after predatory lending reform. http://www.responsiblelending.org/pdfs/HMDA_Study_on_NC_Market.pdf.

Eskridge, Jr., W. N. (1984.) One hundred years of ineptitude: The need for mortgage rules consonant with the economic and psychological dynamics of the home sale and loan transaction. Virginia Law Review 70(6): 1083-1218.

Federal Financial Institutions Examination Council (November 29, 2004.) Memorandum to Chief Executive Officer of Institution subject to the Home Mortgage Disclosure Act;

Harvey K. D. and Nigro, P. J. (2003.) How do predatory lending laws influence mortgage lending in urban areas? A tale of two cities. Journal of Real Estate Research 25(4): 479508.

Harvey, K. D. and Nigro P. J. (2004.) Do predatory lending laws influence mortgage lending? An analysis of the North Carolina predatory lending law. Journal of Real Estate Finance and Economics 29(4): 435-456.

Ho, G. and Pennington-Cross, A. (2006a.) Predatory lending laws and the cost of credit. Research Division, Federal Reserve Bank of St. Louis Working Paper 2006-022A http://research.stlouisfed.org/wp/2006/2006-022.pdf.

Ho, G. and Pennington-Cross, A. (2006b.) The impact of local predatory lending laws on the flow of subprime credit. Journal of Urban Economics 60(2): 210-228.

Ho, G. and Pennington-Cross, A. (January/February 2007.) The varying effects of predatory lending laws on high-cost mortgage applications. Federal Reserve Bank of St. Louis Review 89(1): 39-59. 
Holmes, T. (1998.) The effect of state policies on the location of manufacturing: Evidence from state borders. Journal of Political Economy 106(4): 667-705.

Johnson, C. A. (1995.) Wild card statutes, parity, and national banks-The renascence of state banking powers. Loyola University Chicago Law Journal 26(3): 351-379.

Legal Information Institute (2007.) Consumer credit, Wex

http://www.law.cornell.edu/wex/index.php/Consumer_credit.

Lenders will try to pin down effects of NC mortgage law. Inside $B \& C$ Lending 6(5): 3 (2001).

Li, W. and Ernst, K. (2006.) Do state predatory home lending laws work? Center for Responsible Lending working paper 2006, presented at the AREUEA annual meeting in January.

Li, W. and Ernst, K. (February 23, 2006.) The best value in the subprime market. http://www.responsiblelending.org/pdfs/rr010-State_Effects-0206.pdf.

Litan, R. E. (September 2003.) North Carolina's anti-predatory lending law: Still a problem despite new study. AEI-Brookings Joint Center for Regulatory Studies Regulatory Analysis 03-9.

Lloyd, R. M. (1985.) Refinancing purchase money security interests. Tennessee Law Review 53(1): 1-101.

Morgan Stanley (August 1, 2002.) Channel check: Surprisingly strong subprime growth. Diversified Financials.

Mortgage Bankers Association (March 13, 2007.) Delinquencies and foreclosures increase in latest MBA national delinquency survey. http://www.mortgagebankers.org/NewsandMedia/PressCenter/50974.htm.

National Consumer Law Center (1999.) Truth in Lending, $4^{\text {th }}$ Edition. Washington DC: National Consumer Law Center.

Pence, K. (2006.) Foreclosing on opportunity: State laws and mortgage credit. The Review of Economics and Statistics 88: 177-182.

Pennington-Cross, A. (2002.) Subprime lending in the primary and secondary markets. Journal of Housing Research 13(1): 31-50.

Peterson, C. (2004.) Taming the Sharks: Towards a Cure for the High Cost Credit Market. Akron, OH: University of Akron Press. 
Quercia, R. G., Cowan, S.M. and Moreno, A.B. (December 8, 2005.) The costeffectiveness of community-based foreclosure prevention. working paper http://www.fhfund.org/_dnld/reports/MFP_Full-Report.pdf.

Quercia, R. G., Stegman, M. A. and Davis, W. R. (2004.) Assessing the impact of North Carolina's predatory lending law. Housing Policy Debate 15(3): 573-601.

E. Renuart, K. Keest, K. (2005.) The Cost of Credit: Regulation and Legal Challenges, $3^{\text {rd }}$ Edition. Washington, DC: National Consumer Law Center.

Scheessele, R. M. (1999.) 1998 HMDA highlights. Office of Policy Development and Research Working Paper No. HF-009, U.S. Department of Housing and Urban Development.

Standard \& Poor's (June 17, 2005.) The Subprime Market.

Stegman, M. A., Quercia, R. G. and Davis, W. R. (November 2003.) NC's anti-predatory lending law: Doing what it's supposed to do: A reply. AEI-Brookings Joint Center for Regulatory Studies Related Publication 03-27.

U.S. Department of Housing and Urban Development (2007.) HUD Subprime and Manufactured Home Lender List http://www.huduser.org/datasets/manu.html.

U.S. Office of the Comptroller of the Currency (July 30, 2003.) Economic issues in predatory lending. OCC working paper.

U.S. Office of Thrift Supervision (September 26, 2002.) Responsible Alternative Mortgage Lending. 67 Fed. Reg. 60542.

Whalen, G. (December 1, 2005.) The wealth effects of preemption announcements by the Office of the Comptroller of the Currency after passage of the Georgia Fair Lending Act, working paper http://papers.ssrn.com/sol3/papers.cfm?abstract_id=869038.

Whitman, D. A. (1992.) Mortgage prepayment clauses: An economic and legal analysis. UCLA Law Review 40(4): 851-929.

\section{$\underline{\text { Statutes and Regulations }}$}

Alternative Mortgage Transaction Parity Act, Pub. L. No. 97-320, §§ 801-807, 96 Stat. 1469, 1545-48 (1982).

Home Ownership Equity Protection Act (HOEPA), 15 U.S.C. $§ \S 1601, ~ 1602(a a)$, 1639(a)-(b).

Philadelphia Municipal Ordinance 00-715A (2000). 


\section{Table 1: The North Carolina Anti-Predatory Lending Law}

Stage 1 (effective date October 1, 1999)

These provisions apply to certain closed-end, owner-occupied residential mortgages without regard to APRs or points and fees.

- Bans the following activities

- Balloon payments in home loans (defined as closed-end, first-lien loans of under $\$ 300,000$ ) with terms of over six months

- Prepayment penalties and cap fees in home loans for personal use of under $\$ 150,000$

- Payoff fees in loans under $\$ 300,000$

- Proscribes encouraging consumer home loan borrowers to default

- Prohibits loan flipping (defined as refinancings of consumer home loans without a reasonable, tangible net benefit to the borrowers).

Stage 2 (effective date July 1, 2000)

Most of these provisions apply to high-cost home loans, ${ }^{\text {a }}$ defined as closed-end, owneroccupied loans (other than reverse mortgages) for personal use under Fannie Mae's conforming loan size or $\$ 300,000$ that exceed either one of the following thresholds: ${ }^{b}$

(a) where the APR at consummation exceeds the yield on Treasury securities of comparable maturity plus eight percent (ten percent) for first-lien loans (subordinate-lien loans); or

(b) where total points and fees exceed 5 percent of the total loan amount for loans of $\$ 20,000$ or more, or the lesser of $\$ 1000$ or 8 percent of the total loan amount for loans under $\$ 20,000$. $^{\mathrm{c}}$

- Regulates the following provisions

○ Acceleration clauses

- Balloon payments

○ Negative amortization

- Interest rates upon default

- Advance payments

- Modification and deferral fees

- Loans without regard to ability to repay

- Financing of fees

- Loan flipping

- Payments to home contractors from loan proceeds

- Requires loan applicants to obtain advance loan counseling from a certified counselor in order to close on a high-cost loan.

NOTES: (a) North Carolina provisions banning the financing of single payment credit insurance in consumer home loans did not go into effect until July 1, 2000; (b) 1999 N.C. Sess. Laws 332 (1999), codified at N.C. Gen. Stat. 24-1.1A, 24-1.1E, 24-2.5, 24-8, 24-10.2.; (c) For this trigger, the North Carolina law expanded the definition of "points and fees" beyond the meaning in HOEPA to include other mortgage broker compensation and many large prepayment penalties. N.C. Gen. Stat. § 24-1.1E(6). 
Table 2: States with mini-HOEPA laws (as of January 1, 2007)

\author{
Arkansas \\ California \\ Colorado \\ Connecticut \\ Florida \\ Georgia \\ Illinois \\ Indiana \\ Kentucky \\ Maine \\ Maryland \\ Massachusetts \\ Minnesota \\ Nevada \\ New Hampshire \\ New Jersey \\ New Mexico \\ New York \\ North Carolina \\ Ohio (2006 law only) ${ }^{\text {a }}$ \\ Oklahoma \\ Pennsylvania \\ Rhode Island \\ South Carolina \\ Tennessee \\ Texas \\ Utah \\ West Virginia \\ Wisconsin \\ Washington, D.C.
}

NOTES: (a) Ohio Revised Code $§ 1349.25$ (to take effect on January 1, 2007). In late 2006, before the effective date of the new Ohio law, the state legislature amended these new anti-predatory lending provisions to curtail the strength of the law. The outgoing governor neither signed nor vetoed the amendments. In January 2007, the newly-elected governor vetoed the amendments. There is uncertainty whether the veto will be deemed effective, making uncertain the status of the new Ohio mini-HOEPA law. 
Table 3: Coding rules for scoring state-level anti-predatory lending laws ${ }^{\mathrm{a}}$

\begin{tabular}{|c|c|}
\hline Coverage dimensions & \\
\hline Loan type $^{b}$ & $\begin{array}{l}0 \text { = HOEPA equivalent (excludes home purchase, reverse } \\
\text { mortgages, open-ended loans) } \\
1=\text { law does not cover government loans } \\
2=\text { law does not cover reverse and/or open-ended loans } \\
3 \text { = law does not cover business and/or construction loans } \\
4 \text { = law covers all loans }\end{array}$ \\
\hline $\begin{array}{l}\text { APR trigger for first lien } \\
\text { mortgages }\end{array}$ & $\begin{array}{l}0=\text { HOEPA equivalent ( } 8 \% \text { plus comparable Treasury } \\
\text { security yield) } \\
1=7-8 \% \text { plus the comparable Treasury security yield } \\
2=6-7 \% \text { plus the comparable Treasury security yield } \\
3=\text { no APR trigger }\end{array}$ \\
\hline $\begin{array}{l}\text { APR trigger for } \\
\text { subordinate mortgages }\end{array}$ & $\begin{array}{l}0=\text { HOEPA equivalent }(10 \% \text { plus comparable Treasury } \\
\text { security yield) } \\
1=9-10 \% \text { plus comparable Treasury security yield } \\
2=8-9 \% \text { plus comparable Treasury security yield } \\
3=6-8 \% \text { plus comparable Treasury security yield } \\
4=\text { no APR trigger }\end{array}$ \\
\hline Points and fees trigger ${ }^{c}$ & 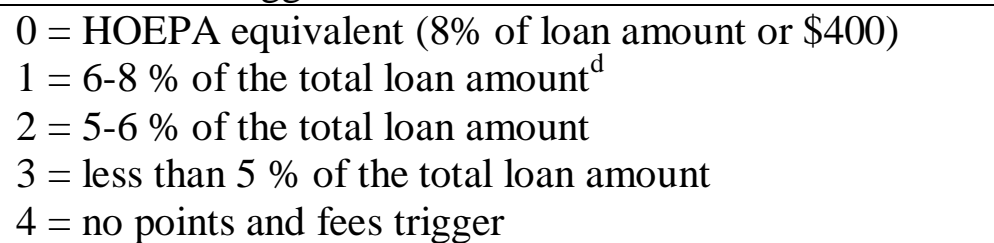 \\
\hline Restrictions dimensions & \\
\hline Prepayment penalties $^{\mathrm{e}}$ & $\begin{array}{l}0=\text { no prepayment penalty restrictions } \\
1=\text { bans all penalties } 60-84 \text { months after origination } \\
2=\text { bans all penalties } 36-42 \text { months after origination } \\
3=\text { bans all penalties } 24 \text { months after origination } \\
4=\text { bans all prepayment penalties }\end{array}$ \\
\hline Balloon payments $^{f}$ & $\begin{array}{l}0=\text { no restriction } \\
1=\text { no balloons allowed in first } 7 \text { years of loan } \\
2=\text { no balloons allowed in first } 10 \text { years of loan } \\
3=\text { no balloons allowed after } 10 \text { or more years of loan } \\
4=\text { no balloons allowed }\end{array}$ \\
\hline $\begin{array}{l}\text { Credit counseling } \\
\text { requirements }^{\mathrm{g}}\end{array}$ & $\begin{array}{l}0=\text { credit counseling not required } \\
1=\text { credit counseling recommended or lender must give } \\
\text { borrowers notice of right to/value of credit counseling } \\
2=\text { credit counseling is required }\end{array}$ \\
\hline $\begin{array}{l}\text { Limits on judicial relief/ } \\
\text { mandatory arbitration }\end{array}$ & $\begin{array}{l}0=\text { does not prohibit restrictions on judicial relief }^{\mathrm{i}} \text { and } \\
\text { mandatory arbitration } \\
1=\text { limits }^{\mathrm{j}} \text { restrictions on judicial relief and mandatory } \\
\text { arbitration } \\
2=\text { prohibits mandatory arbitration and other restrictions } \\
\text { on judicial relief }\end{array}$ \\
\hline Enforcement mechanisms & \\
\hline
\end{tabular}




\begin{tabular}{|c|c|}
\hline Assignee liability ${ }^{k}$ & $\begin{array}{l}0=\text { no assignee liability for holders in due course } \\
1=\text { borrowers can only seek relief against assignees as } \\
\text { defenses, including claims of recoupment, to assignee } \\
\text { foreclosure and/ or collection actions } \\
2=\text { Hold liable only those assignees who do not exercise } \\
\text { due diligence } \\
3=\text { even if assignees exercised due diligence, they may be } \\
\text { subject to limited claims and defenses or assignees are } \\
\text { liable for willful violations by originators regardless of } \\
\text { any due diligence } \\
4=\text { assignees are liable even if they exercise due diligence }\end{array}$ \\
\hline $\begin{array}{l}\text { Enforcement against } \\
\text { originators } 1\end{array}$ & $\begin{array}{l}0=\text { only the state government can enforce anti-predatory } \\
\text { lending laws } \\
1=\text { borrowers have a private right of action and can } \\
\text { recover compensatory, but no punitive damages, statutory } \\
\text { damages that are non-compensatory, }{ }^{m} \text { or civil penalties } \\
2=\text { borrowers can bring private lawsuits and recover } \\
\text { compensatory damages, and punitive damages, statutory } \\
\text { non-compensatory damages or civil penalties }\end{array}$ \\
\hline
\end{tabular}

NOTES: (a) The index includes only laws that were in effect by January 1, 2005; (b) This measure is coded using the most conservative assessment of coverage. For example, a law that excludes coverage for business loans and open-ended loans is coded 2. Laws that exclude consumer credit transactions or loans for personal use are coded as excluding business loans.; (c) If a law's points and fees triggers varied based on the amount of the loan, we scored the law based on the triggers that applied to the largest loan amount. The $\$ 400$ trigger is indexed annually for inflation; (d) If the law extends HOEPA in other ways without changing the trigger and the trigger is not 6 percent or lower of the total loan amount, the score equals 1.; (e) Laws that permit reasonable and necessary prepayment penalties are coded as 0 . If a law uses prepayment penalties to determine coverage triggers, but does not ban prepayment penalties, it is assigned a 0. ; (f) Laws that prohibit balloon payments larger than twice the monthly payment without any restrictions in time were scored as a 4.; (g) If counseling is required for some but not all types of loans, the score is 2. Similarly, if counseling was recommended for any type of loan the score is a 1.; (h) Laws that ban unconscionable arbitration terms receive a score of 1.; (i) Restrictions on judicial relief include provisions requiring borrowers to resolve disputes in a less convenient, more expensive forum than the one in which the borrower otherwise could have brought the claim.; (j) For example, a law may prohibit mandatory arbitration clauses that do not require the lenders to pay half the filing fee or do not obligate the lender to pay its own and the borrowers' arbitration fees for the first day of arbitration.; (k) If borrowers can obtain rescission against assignees, the measure is assigned a 4 . If the law precludes assignee liability unless the violation is apparent on the face of the loan documents, the score is 0 . However, for any law for which all violations would be apparent on the face of the loan documents, assignees could not be deemed holders in due course and, therefore, such laws are assigned a 4.; (l) If the law provides that violations of the antipredatory lending law would give rise to claims under the state unfair and deceptive trade practices (UDAP) laws, the relief is coded according to the UDAP law. If the only remedy available is refund of an unlawful prepayment penalty, this measure is coded as a 1; (m) This includes laws that permit borrowers to recover an amount equal to a set multiplier times actual damages. 
Table 4: New Laws Index - Mini-HOEPA Laws, 2004-2005

\begin{tabular}{|c|c|c|c|c|c|}
\hline State & Coverage & Restrictions & Enforcement & $\begin{array}{l}\text { Index }^{A} \text {-- } \\
\text { Additive }\end{array}$ & $\begin{array}{c}\text { Index }^{\mathrm{M}} \text {-- } \\
\text { Multiplicative }\end{array}$ \\
\hline Alaska & 0.00 & 0.00 & 0.00 & 0.00 & 0.00 \\
\hline Alabama & 0.00 & 0.00 & 0.00 & 0.00 & 0.00 \\
\hline Arizona & 0.00 & 0.00 & 0.00 & 0.00 & 0.00 \\
\hline Arkansas & 1.72 & 2.73 & 2.11 & 6.56 & 9.92 \\
\hline California & 2.15 & 1.36 & 1.41 & 4.93 & 4.13 \\
\hline Colorado & 0.43 & 1.64 & 2.11 & 4.18 & 1.49 \\
\hline Connecticut & 0.86 & 1.91 & 2.11 & 4.88 & 3.47 \\
\hline Delaware & 0.00 & 0.00 & 0.00 & 0.00 & 0.00 \\
\hline District of Columbia & 3.74 & 1.91 & 2.11 & 7.75 & 15.05 \\
\hline Florida & 0.00 & 1.64 & 2.11 & 3.75 & 0.00 \\
\hline Georgia & 1.72 & 3.00 & 2.11 & 6.83 & 10.91 \\
\hline Hawaii & 0.00 & 0.00 & 0.00 & 0.00 & 0.00 \\
\hline Idaho & 0.00 & 0.00 & 0.00 & 0.00 & 0.00 \\
\hline Illinois & 3.74 & 1.91 & 2.46 & 8.11 & 17.56 \\
\hline Indiana & 1.29 & 3.00 & 2.46 & 6.76 & 9.55 \\
\hline Iowa & 0.00 & 0.00 & 0.00 & 0.00 & 0.00 \\
\hline Kansas & 0.00 & 0.00 & 0.00 & 0.00 & 0.00 \\
\hline Kentucky & 0.86 & 2.18 & 2.81 & 5.86 & 5.29 \\
\hline Louisiana & 0.00 & 0.00 & 0.00 & 0.00 & 0.00 \\
\hline Maine & 0.00 & 0.55 & 2.46 & 3.01 & 0.00 \\
\hline Maryland & 1.44 & 0.55 & 1.41 & 3.39 & 1.10 \\
\hline Massachusetts & 2.15 & 3.82 & 2.46 & 8.44 & 20.26 \\
\hline Michigan & 5.17 & 0.82 & 0.00 & 5.99 & 0.00 \\
\hline Minnesota & 6.46 & 0.55 & 0.00 & 7.01 & 0.00 \\
\hline Mississippi & 0.00 & 0.00 & 0.00 & 0.00 & 0.00 \\
\hline Missouri & 0.00 & 0.00 & 0.00 & 0.00 & 0.00 \\
\hline Montana & 0.00 & 0.00 & 0.00 & 0.00 & 0.00 \\
\hline Nebraska & 0.00 & 0.00 & 0.00 & 0.00 & 0.00 \\
\hline Nevada & 0.00 & 0.00 & 2.81 & 2.81 & 0.00 \\
\hline New Hampshire & 0.00 & 0.00 & 0.00 & 0.00 & 0.00 \\
\hline New Jersey & 2.15 & 2.73 & 2.46 & 7.34 & 14.47 \\
\hline New Mexico & 4.17 & 3.27 & 2.46 & 9.90 & 33.57 \\
\hline New York & 2.15 & 1.91 & 1.76 & 5.82 & 7.23 \\
\hline North Carolina & 1.72 & 3.27 & 1.41 & 6.40 & 7.94 \\
\hline North Dakota & 0.00 & 0.00 & 0.00 & 0.00 & 0.00 \\
\hline Ohio & 0.00 & 1.36 & 2.11 & 3.47 & 0.00 \\
\hline Oklahoma & 0.00 & 2.18 & 2.11 & 4.29 & 0.00 \\
\hline Oregon & 0.00 & 0.00 & 0.00 & 0.00 & 0.00 \\
\hline Pennsylvania & 0.00 & 1.36 & 2.11 & 3.47 & 0.00 \\
\hline Rhode Island & 0.00 & 0.00 & 0.00 & 0.00 & 0.00 \\
\hline South Carolina & 0.86 & 2.18 & 1.76 & 4.80 & 3.31 \\
\hline South Dakota & 0.00 & 0.00 & 0.00 & 0.00 & 0.00 \\
\hline Tennessee & 0.00 & 0.00 & 0.00 & 0.00 & 0.00 \\
\hline Texas & 0.86 & 1.36 & 2.11 & 4.34 & 2.48 \\
\hline Utah & 1.72 & 2.18 & 0.00 & 3.91 & 0.00 \\
\hline Vermont & 0.00 & 0.00 & 0.00 & 0.00 & 0.00 \\
\hline Virginia & 0.00 & 0.00 & 0.00 & 0.00 & 0.00 \\
\hline Washington & 0.00 & 0.00 & 0.00 & 0.00 & 0.00 \\
\hline West Virginia & 5.60 & 1.64 & 1.76 & 9.00 & 16.12 \\
\hline Wisconsin & 0.00 & 0.00 & 0.00 & 0.00 & 0.00 \\
\hline Wyoming & 0.00 & 0.00 & 0.00 & 0.00 & 0.00 \\
\hline Average & 1.00 & 1.00 & 1.00 & 3.00 & 3.61 \\
\hline Min & 0.00 & 0.00 & 0.00 & 0.00 & 0.00 \\
\hline $\operatorname{Max}$ & 6.46 & 3.82 & 2.81 & 9.90 & 33.57 \\
\hline Standard Deviation & 1.62 & 1.17 & 1.10 & 3.19 & 6.90 \\
\hline
\end{tabular}

If all columns are zeros then no law was identified. 
Table 5: Old or Preexisting Law Index - Enacted Before Mini-HOEPA Laws and In Effect 2004-2005

\begin{tabular}{|c|c|c|c|c|c|}
\hline State & Coverage & Restrictions & Enforcement & $\begin{array}{l}\text { Index }^{A} \text {-- } \\
\text { Additive }\end{array}$ & $\begin{array}{c}\text { Index }^{\mathrm{M}}-- \\
\text { Multiplicative }\end{array}$ \\
\hline Alaska & 1.69 & 2.68 & 0.64 & 5.02 & 2.91 \\
\hline Alabama & 1.57 & 2.68 & 2.57 & 6.82 & 10.82 \\
\hline Arizona & 0.00 & 0.00 & 0.00 & 0.00 & 0.00 \\
\hline Arkansas & 1.93 & 1.34 & 0.00 & 3.28 & 0.00 \\
\hline California & 1.93 & 0.67 & 1.92 & 4.53 & 2.50 \\
\hline Colorado & 1.45 & 2.68 & 1.92 & 6.06 & 7.49 \\
\hline Connecticut & 1.81 & 1.34 & 0.00 & 3.15 & 0.00 \\
\hline Delaware & 0.00 & 0.00 & 0.00 & 0.00 & 0.00 \\
\hline District of Columbia & 1.93 & 1.34 & 1.28 & 4.56 & 3.33 \\
\hline Florida & 0.00 & 0.00 & 0.00 & 0.00 & 0.00 \\
\hline Georgia & 0.00 & 0.00 & 0.00 & 0.00 & 0.00 \\
\hline Hawaii & 0.85 & 0.67 & 1.92 & 3.44 & 1.09 \\
\hline Idaho & 1.81 & 1.34 & 2.57 & 5.72 & 6.24 \\
\hline Illinois & 0.00 & 0.00 & 0.00 & 0.00 & 0.00 \\
\hline Indiana & 1.93 & 1.34 & 1.92 & 5.20 & 4.99 \\
\hline Iowa & 1.93 & 2.68 & 0.64 & 5.26 & 3.33 \\
\hline Kansas & 1.93 & 2.68 & 2.57 & 7.18 & 13.32 \\
\hline Kentucky & 1.57 & 0.67 & 1.92 & 4.17 & 2.03 \\
\hline Louisiana & 1.81 & 0.67 & 0.00 & 2.48 & 0.00 \\
\hline Maine & 1.57 & 2.68 & 1.92 & 6.18 & 8.12 \\
\hline Maryland & 1.57 & 2.68 & 2.57 & 6.82 & 10.82 \\
\hline Massachusetts & 0.00 & 0.00 & 0.00 & 0.00 & 0.00 \\
\hline Michigan & 1.57 & 1.34 & 0.96 & 3.88 & 2.03 \\
\hline Minnesota & 0.00 & 0.00 & 0.00 & 0.00 & 0.00 \\
\hline Mississippi & 1.93 & 0.67 & 1.92 & 4.53 & 2.50 \\
\hline Missouri & 1.81 & 0.67 & 1.92 & 4.41 & 2.34 \\
\hline Montana & 0.00 & 0.00 & 0.00 & 0.00 & 0.00 \\
\hline Nebraska & 1.93 & 0.00 & 0.64 & 2.58 & 0.00 \\
\hline Nevada & 0.00 & 0.00 & 0.00 & 0.00 & 0.00 \\
\hline New Hampshire & 0.00 & 0.00 & 0.00 & 0.00 & 0.00 \\
\hline New Jersey & 0.00 & 0.00 & 0.00 & 0.00 & 0.00 \\
\hline New Mexico & 1.93 & 2.68 & 2.57 & 7.18 & 13.32 \\
\hline New York & 0.00 & 0.00 & 0.00 & 0.00 & 0.00 \\
\hline North Carolina & 1.69 & 1.34 & 1.92 & 4.96 & 4.37 \\
\hline North Dakota & 0.00 & 0.00 & 0.00 & 0.00 & 0.00 \\
\hline Ohio & 1.93 & 0.67 & 1.92 & 4.53 & 2.50 \\
\hline Oklahoma & 0.97 & 2.68 & 2.57 & 6.22 & 6.66 \\
\hline Oregon & 0.00 & 0.00 & 0.00 & 0.00 & 0.00 \\
\hline Pennsylvania & 0.00 & 0.00 & 0.00 & 0.00 & 0.00 \\
\hline Rhode Island & 1.93 & 2.01 & 0.00 & 3.95 & 0.00 \\
\hline South Carolina & 1.93 & 2.68 & 2.57 & 7.18 & 13.32 \\
\hline South Dakota & 0.00 & 0.00 & 0.00 & 0.00 & 0.00 \\
\hline Tennessee & 0.00 & 0.00 & 0.00 & 0.00 & 0.00 \\
\hline Texas & 0.00 & 0.00 & 0.00 & 0.00 & 0.00 \\
\hline Utah & 1.81 & 2.68 & 2.57 & 7.06 & 12.49 \\
\hline Vermont & 1.57 & 2.68 & 1.92 & 6.18 & 8.12 \\
\hline Virginia & 1.81 & 0.00 & 2.57 & 4.38 & 0.00 \\
\hline Washington & 0.00 & 0.00 & 0.00 & 0.00 & 0.00 \\
\hline West Virginia & 0.00 & 0.00 & 0.00 & 0.00 & 0.00 \\
\hline Wisconsin & 0.00 & 0.00 & 0.00 & 0.00 & 0.00 \\
\hline Wyoming & 0.85 & 2.68 & 2.57 & 6.10 & 5.83 \\
\hline Average & 1.00 & 1.00 & 1.00 & 3.00 & 2.95 \\
\hline Min & 0.00 & 0.00 & 0.00 & 0.00 & 0.00 \\
\hline $\operatorname{Max}$ & 1.93 & 2.68 & 2.57 & 7.18 & 13.32 \\
\hline Standard Deviation & 0.88 & 1.12 & 1.09 & 2.75 & 4.22 \\
\hline
\end{tabular}


If all columns are zeros then no law was identified. 
Table 6: Complete or Combined Index, 2004-2005

\begin{tabular}{|c|c|c|c|c|c|}
\hline State & Coverage & Restrictions & Enforcement & $\begin{array}{l}\text { Index }{ }^{A} \text {-- } \\
\text { Additive }\end{array}$ & $\begin{array}{c}\text { Index }^{\mathrm{M}}-- \\
\text { Multiplicative }\end{array}$ \\
\hline Alaska & 1.69 & 2.68 & 0.64 & 5.02 & 2.91 \\
\hline Alabama & 1.57 & 2.68 & 2.57 & 6.82 & 10.82 \\
\hline Arizona & 0.00 & 0.00 & 0.00 & 0.00 & 0.00 \\
\hline Arkansas & 3.66 & 4.07 & 2.11 & 9.84 & 9.92 \\
\hline California & 4.09 & 2.03 & 3.33 & 9.45 & 6.63 \\
\hline Colorado & 1.88 & 4.32 & 4.03 & 10.24 & 8.98 \\
\hline Connecticut & 2.67 & 3.25 & 2.11 & 8.04 & 3.47 \\
\hline Delaware & 0.00 & 0.00 & 0.00 & 0.00 & 0.00 \\
\hline District of Columbia & 5.67 & 3.25 & 3.39 & 12.31 & 18.38 \\
\hline Florida & 0.00 & 1.64 & 2.11 & 3.75 & 0.00 \\
\hline Georgia & 1.72 & 3.00 & 2.11 & 6.83 & 10.91 \\
\hline Hawaii & 0.85 & 0.67 & 1.92 & 3.44 & 1.09 \\
\hline Idaho & 1.81 & 1.34 & 2.57 & 5.72 & 6.24 \\
\hline Illinois & 3.74 & 1.91 & 2.46 & 8.11 & 17.56 \\
\hline Indiana & 3.23 & 4.34 & 4.39 & 11.96 & 14.54 \\
\hline Iowa & 1.93 & 2.68 & 0.64 & 5.26 & 3.33 \\
\hline Kansas & 1.93 & 2.68 & 2.57 & 7.18 & 13.32 \\
\hline Kentucky & 2.43 & 2.85 & 4.74 & 10.02 & 7.32 \\
\hline Louisiana & 1.81 & 0.67 & 0.00 & 2.48 & 0.00 \\
\hline Maine & 1.57 & 3.23 & 4.39 & 9.19 & 8.12 \\
\hline Maryland & 3.01 & 3.23 & 3.97 & 10.21 & 11.92 \\
\hline Massachusetts & 2.15 & 3.82 & 2.46 & 8.44 & 20.26 \\
\hline Michigan & 6.74 & 2.16 & 0.96 & 9.87 & 2.03 \\
\hline Minnesota & 6.46 & 0.55 & 0.00 & 7.01 & 0.00 \\
\hline Mississippi & 1.93 & 0.67 & 1.92 & 4.53 & 2.50 \\
\hline Missouri & 1.81 & 0.67 & 1.92 & 4.41 & 2.34 \\
\hline Montana & 0.00 & 0.00 & 0.00 & 0.00 & 0.00 \\
\hline Nebraska & 1.93 & 0.00 & 0.64 & 2.58 & 0.00 \\
\hline Nevada & 0.00 & 0.00 & 2.81 & 2.81 & 0.00 \\
\hline New Hampshire & 0.00 & 0.00 & 0.00 & 0.00 & 0.00 \\
\hline New Jersey & 2.15 & 2.73 & 2.46 & 7.34 & 14.47 \\
\hline New Mexico & 6.10 & 5.96 & 5.03 & 17.08 & 46.89 \\
\hline New York & 2.15 & 1.91 & 1.76 & 5.82 & 7.23 \\
\hline North Carolina & 3.42 & 4.61 & 3.33 & 11.36 & 12.31 \\
\hline North Dakota & 0.00 & 0.00 & 0.00 & 0.00 & 0.00 \\
\hline Ohio & 1.93 & 2.03 & 4.03 & 8.00 & 2.50 \\
\hline Oklahoma & 0.97 & 4.87 & 4.68 & 10.51 & 6.66 \\
\hline Oregon & 0.00 & 0.00 & 0.00 & 0.00 & 0.00 \\
\hline Pennsylvania & 0.00 & 1.36 & 2.11 & 3.47 & 0.00 \\
\hline Rhode Island & 1.93 & 2.01 & 0.00 & 3.95 & 0.00 \\
\hline South Carolina & 2.80 & 4.87 & 4.32 & 11.99 & 16.63 \\
\hline South Dakota & 0.00 & 0.00 & 0.00 & 0.00 & 0.00 \\
\hline Tennessee & 0.00 & 0.00 & 0.00 & 0.00 & 0.00 \\
\hline Texas & 0.86 & 1.36 & 2.11 & 4.34 & 2.48 \\
\hline Utah & 3.54 & 4.87 & 2.57 & 10.97 & 12.49 \\
\hline Vermont & 1.57 & 2.68 & 1.92 & 6.18 & 8.12 \\
\hline Virginia & 1.81 & 0.00 & 2.57 & 4.38 & 0.00 \\
\hline Washington & 0.00 & 0.00 & 0.00 & 0.00 & 0.00 \\
\hline West Virginia & 5.60 & 1.64 & 1.76 & 9.00 & 16.12 \\
\hline Wisconsin & 0.00 & 0.00 & 0.00 & 0.00 & 0.00 \\
\hline Wyoming & 0.85 & 2.68 & 2.57 & 6.10 & 5.83 \\
\hline Average & 2.00 & 2.00 & 2.00 & 6.00 & 6.56 \\
\hline Min & 0.00 & 0.00 & 0.00 & 0.00 & 0.00 \\
\hline $\operatorname{Max}$ & 8.40 & 6.50 & 5.38 & 17.08 & 46.89 \\
\hline Standard Deviation & 2.50 & 2.29 & 2.19 & 4.18 & 8.39 \\
\hline
\end{tabular}

If all columns are zeros then no law was identified. 
Table 7: Distribution of Originations on State Borders

\begin{tabular}{|c|c|c|c|c|c|}
\hline State Border & 2004 & 2005 & State Border & 2004 & 2005 \\
\hline ALFL & 0.01 & 0.01 & KSOK & 0.00 & 0.00 \\
\hline ALGA & 0.01 & 0.01 & KSNE & & 0.00 \\
\hline ALMS & 0.01 & 0.01 & KYTN & 0.01 & 0.01 \\
\hline ALTN & 0.01 & 0.01 & $\mathrm{KYOH}$ & 0.02 & 0.02 \\
\hline ARLA & 0.00 & 0.00 & KYWV & 0.00 & 0.00 \\
\hline ARMO & 0.00 & 0.01 & KYMO & & 0.00 \\
\hline AROK & 0.01 & 0.01 & KYVA & & 0.00 \\
\hline ARTN & 0.01 & 0.01 & LATX & 0.01 & 0.01 \\
\hline ARMS & 0.00 & 0.00 & LAMS & 0.00 & 0.00 \\
\hline AZNM & 0.00 & 0.00 & MANY & 0.00 & 0.00 \\
\hline AZUT & & 0.01 & MARI & & 0.02 \\
\hline AZCA & 0.00 & 0.01 & MANH & & \\
\hline AZNV & 0.05 & 0.05 & MAVT & & 0.00 \\
\hline CANV & 0.12 & 0.11 & MDPA & 0.05 & 0.05 \\
\hline CAOR & 0.00 & 0.01 & MDWV & 0.00 & 0.00 \\
\hline ARCA & 0.11 & 0.09 & MDVA & 0.05 & 0.04 \\
\hline CONM & & 0.00 & MENH & 0.01 & \\
\hline COKS & 0.00 & 0.00 & MIWI & & \\
\hline COUT & & 0.00 & $\mathrm{MIOH}$ & 0.01 & 0.01 \\
\hline COWY & 0.01 & 0.01 & MNSD & 0.00 & 0.00 \\
\hline CONE & & 0.00 & MNWI & 0.02 & \\
\hline CTNY & 0.03 & 0.02 & MNND & 0.00 & 0.00 \\
\hline СТМА & & 0.02 & MONE & & 0.00 \\
\hline CTRI & 0.01 & 0.02 & MOOK & 0.00 & 0.00 \\
\hline DCVA & 0.01 & 0.01 & MOTN & & 0.00 \\
\hline DEMD & 0.01 & 0.02 & MSTN & 0.01 & 0.01 \\
\hline FLGA & 0.01 & 0.01 & MTWY & & 0.00 \\
\hline GASC & 0.01 & 0.01 & NCVA & 0.02 & 0.02 \\
\hline GATN & 0.01 & 0.01 & NCSC & 0.04 & 0.04 \\
\hline GANC & & 0.00 & NCTN & 0.00 & 0.01 \\
\hline IAWI & 0.00 & & NEWY & 0.00 & 0.00 \\
\hline IAMO & & 0.00 & NESD & 0.00 & 0.00 \\
\hline IAIL & 0.01 & 0.00 & NHVT & & \\
\hline IAMN & & 0.00 & NJNY & 0.05 & 0.04 \\
\hline IASD & 0.00 & 0.00 & NJPA & 0.07 & 0.07 \\
\hline IANE & 0.01 & 0.01 & NMTX & 0.01 & 0.01 \\
\hline IDNV & & 0.00 & NVUT & & 0.01 \\
\hline IDOR & 0.00 & 0.00 & NVOR & 0.01 & 0.01 \\
\hline IDUT & & 0.00 & NYPA & 0.01 & 0.01 \\
\hline IDWA & 0.01 & 0.01 & NYVT & 0.00 & 0.01 \\
\hline IDMT & 0.00 & 0.00 & OHPA & 0.01 & 0.01 \\
\hline IDWY & 0.00 & 0.00 & OHWV & 0.00 & 0.00 \\
\hline ILMO & 0.04 & 0.03 & OKTX & 0.00 & 0.00 \\
\hline ILWI & 0.03 & 0.00 & DEPA & 0.02 & 0.02 \\
\hline ILIN & 0.10 & 0.09 & PAWV & 0.01 & 0.00 \\
\hline ILKY & & 0.00 & SDWY & 0.00 & 0.00 \\
\hline INOH & 0.02 & 0.02 & TNVA & 0.00 & 0.00 \\
\hline INKY & 0.02 & 0.02 & ARTX & 0.00 & 0.00 \\
\hline INMI & 0.01 & 0.01 & UTWY & & 0.00 \\
\hline KSMO & 0.03 & 0.03 & VAWV & 0.01 & 0.01 \\
\hline
\end{tabular}

Missing information indicates that loans on that border are excluded from the sample either due to a law coming into effect during the year or insufficient sample size (less than 0.001 percent of the sample). 
Table 8: Variable Definitions

\begin{tabular}{|c|c|c|}
\hline Variable & Definition & Source \\
\hline \multicolumn{3}{|l|}{ Outcome Variables } \\
\hline Origination (price ID) & $\begin{array}{l}\text { Indicator variable }=1 \text { for subprime origination; } \\
0 \text { for prime origination; Subprime loans } \\
\text { identified by reported APR spread }\end{array}$ & HMDA \\
\hline Origination (list ID) & $\begin{array}{l}\text { Indicator variable }=1 \text { for subprime application; } \\
0 \text { for prime application; Subprime loans } \\
\text { identified by HUD subprime lender list }\end{array}$ & HMDA \& HUD \\
\hline Application & $\begin{array}{l}\text { Indicator variable }=1 \text { for subprime application; } \\
0 \text { for prime application; Subprime loans } \\
\text { identified by HUD subprime lender list }\end{array}$ & HMDA \& HUD \\
\hline Rejection & $\begin{array}{l}\text { Indicator variable }=1 \text { for rejected subprime } \\
\text { application; } 0 \text { for accepted subprime application; } \\
\text { Subprime loans identified by HUD subprime } \\
\text { lender list }\end{array}$ & HMDA \& HUD \\
\hline \multicolumn{3}{|l|}{ Control Variables } \\
\hline Income (thousands \$) & Borrower's gross annual income (in thousands \$) & HMDA \\
\hline Loan2inc & $\begin{array}{l}\text { Ratio of requested loan amount to borrower's } \\
\text { income }\end{array}$ & HMDA \\
\hline Minority & Tract's minority population percentage & HMDA \\
\hline Population & $\begin{array}{l}\text { County's percentage growth over the prior } \\
\text { calendar year }\end{array}$ & Census Bureau \\
\hline Vacant & County's percentage of vacant housing units & Census Bureau \\
\hline Unemployment & County's unemployment rate & $\begin{array}{l}\text { Bureau of Labor and } \\
\text { Statistics }\end{array}$ \\
\hline Density & $\begin{array}{l}\text { Census tract population density (100's per } \\
\text { square mile) }\end{array}$ & Census Bureau \\
\hline OCC & $\begin{array}{l}\text { Lending institution regulated by the Office of } \\
\text { Currency Comptroller }\end{array}$ & HMDA \\
\hline
\end{tabular}

During estimation income is expressed in millions, all percentages are expressed as fractions. 
Table 9: Descriptive Statistics

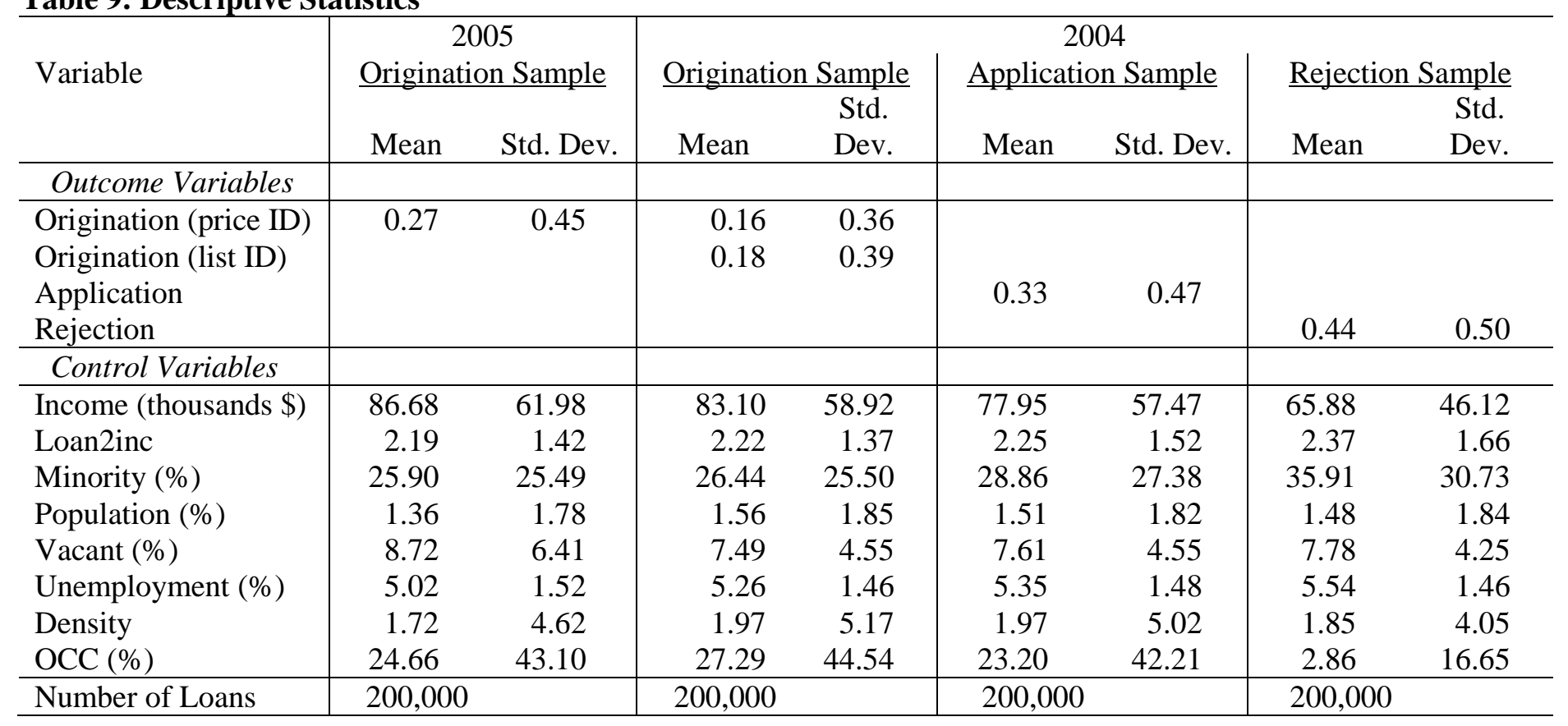


Table 10: Logit Base Model Results - Origination

\begin{tabular}{|c|c|c|c|c|c|c|}
\hline Year & \multicolumn{4}{|c|}{2004} & \multirow{2}{*}{\multicolumn{2}{|c|}{$\begin{array}{c}2005 \\
\text { HMDA Price }\end{array}$}} \\
\hline Subprime def. & \multicolumn{2}{|c|}{ HUD List } & \multicolumn{2}{|c|}{ HMDA Price } & & \\
\hline Variable & Estimate & $\begin{array}{l}\text { Odds } \\
\text { Ratio }\end{array}$ & Estimate & $\begin{array}{l}\text { Odds } \\
\text { Ratio }\end{array}$ & Estimate & $\begin{array}{l}\text { Odds } \\
\text { Ratio }\end{array}$ \\
\hline Intercept & $\begin{array}{l}-1.28 * * \\
(0.07)\end{array}$ & -- & $\begin{array}{l}-0.77 * * \\
(0.07)\end{array}$ & -- & $\begin{array}{l}-0.75^{* *} \\
(0.06)\end{array}$ & -- \\
\hline ineffect & $\begin{array}{l}0.07 \\
(0.05)\end{array}$ & 1.07 & $\begin{array}{l}-0.06 \\
(0.05)\end{array}$ & 0.95 & $\begin{array}{l}0.03 \\
(0.04)\end{array}$ & 1.03 \\
\hline Income & $\begin{array}{l}-5.57 * * \\
(0.16)\end{array}$ & 0.95 & $\begin{array}{l}-8.31 * * \\
(0.18)\end{array}$ & 0.92 & $\begin{array}{l}-5.68 * * \\
(0.12)\end{array}$ & 0.94 \\
\hline Loan2inc & $\begin{array}{l}-0.01^{*} \\
(0.00)\end{array}$ & 0.99 & $\begin{array}{l}-0.27 * * \\
(0.01)\end{array}$ & 0.76 & $\begin{array}{l}-0.14 * * \\
(0.00)\end{array}$ & 0.87 \\
\hline Minority & $\begin{array}{l}1.59 * * \\
(0.03)\end{array}$ & 4.9 & $\begin{array}{l}1.56 * * \\
(0.03)\end{array}$ & 4.77 & $\begin{array}{l}1.68 * * \\
(0.02)\end{array}$ & 5.34 \\
\hline Vacant & $\begin{array}{l}-0.42 \\
(0.22)\end{array}$ & 0.66 & $\begin{array}{l}0.47 * \\
(0.21)\end{array}$ & 1.61 & $\begin{array}{l}-0.09 \\
(0.12)\end{array}$ & 0.91 \\
\hline Population & $\begin{array}{l}2.03 * * \\
(0.64)\end{array}$ & 7.58 & $\begin{array}{l}-1.42 * \\
(0.68)\end{array}$ & 0.24 & $\begin{array}{l}0.83 \\
(0.49)\end{array}$ & 2.30 \\
\hline Unemployment & $\begin{array}{l}2.52 * * \\
(0.72)\end{array}$ & 1.03 & $\begin{array}{l}3.05 * * \\
(0.72)\end{array}$ & 1.03 & $\begin{array}{l}3.22 * * \\
(0.51)\end{array}$ & 1.03 \\
\hline Density & $\begin{array}{l}-0.02 * * \\
(0.00)\end{array}$ & 0.98 & $\begin{array}{l}-0.03 * * \\
(0.00)\end{array}$ & 0.97 & $\begin{array}{l}-0.03 * * \\
(0.00)\end{array}$ & 0.97 \\
\hline OCC & $\begin{array}{l}-4.25^{* *} \\
(0.06) \\
\end{array}$ & 0.01 & & 0.27 & $\begin{array}{l}-1.09 * * \\
(0.01)\end{array}$ & 0.34 \\
\hline Log Likelihood & $-78,948$ & & $-78,189$ & & $-107,182$ & \\
\hline
\end{tabular}

NOTES: Standard errors are in parentheses. * Significance at 5\% level. ** Significance at the $1 \%$ level. State-County border pair fixed effects included in all specifications. NCVA is the excluded border area. State-County border pair coefficient estimates are available on request from the authors. 
Table 11: Logit Base Model Results - Application and Rejection rates

\begin{tabular}{|c|c|c|c|c|}
\hline Year & \multicolumn{4}{|c|}{2004} \\
\hline Dep. Var. & \multicolumn{2}{|c|}{ Applications } & \multicolumn{2}{|c|}{ Rejection rates } \\
\hline Variable & Estimate & $\begin{array}{l}\text { Odds } \\
\text { Ratio }\end{array}$ & Estimate & $\begin{array}{l}\text { Odds } \\
\text { Ratio }\end{array}$ \\
\hline Intercept & $\begin{array}{l}-0.60^{* *} \\
(0.06)\end{array}$ & -- & $\begin{array}{l}-0.30^{* *} \\
(0.05)\end{array}$ & -- \\
\hline ineffect & $\begin{array}{l}0.05 \\
(0.04)\end{array}$ & 1.05 & $\begin{array}{l}-0.08^{*} \\
(0.04)\end{array}$ & 0.93 \\
\hline Income & $\begin{array}{l}-4.64 * * \\
(0.12)\end{array}$ & 0.95 & $\begin{array}{l}-1.90^{* *} \\
(0.12)\end{array}$ & 0.98 \\
\hline Loan2inc & $\begin{array}{l}0.04 * * \\
(0.00)\end{array}$ & 1.04 & $\begin{array}{l}0.06^{* * *} \\
(0.00)\end{array}$ & 1.06 \\
\hline Minority & $\begin{array}{l}1.28 * * \\
(0.02)\end{array}$ & 3.61 & $\begin{array}{l}0.12 * * \\
(0.02)\end{array}$ & 1.13 \\
\hline Vacant & $\begin{array}{l}-0.26 \\
(0.17)\end{array}$ & 0.77 & $\begin{array}{l}-0.37^{*} \\
(0.16)\end{array}$ & 0.69 \\
\hline Population & $\begin{array}{l}0.47 \\
(0.54)\end{array}$ & 1.61 & $\begin{array}{l}-0.69 \\
(0.49)\end{array}$ & 0.50 \\
\hline Unemployment & $\begin{array}{l}4.36^{* * *} \\
(0.62)\end{array}$ & 1.04 & $\begin{array}{l}5.36 * * \\
(0.53)\end{array}$ & 1.06 \\
\hline Density & $\begin{array}{l}-0.02 * * \\
(0.00)\end{array}$ & 0.98 & $\begin{array}{l}0.00^{*} \\
(0.00)\end{array}$ & 1.00 \\
\hline OCC & $\begin{array}{l}-3.19^{* * *} \\
(0.03)\end{array}$ & 0.04 & $\begin{array}{l}-0.53^{* * *} \\
(0.03)\end{array}$ & 0.59 \\
\hline Log Likelihood & $-106,164$ & & $-134,143$ & \\
\hline
\end{tabular}

NOTES: Standard errors are in parentheses. * Significance at 5\% level. ** Significance at the $1 \%$ level. State-County border pair fixed effects included in all specifications. NCVA is the excluded border area. State-County border pair coefficient estimates are available on request from the authors. 
Table 12: Logit Results for Alternative Model Specifications

A. 2004 Originations, HUD List Definition of Subprime

\begin{tabular}{|c|c|c|c|c|c|c|c|c|}
\hline \multirow[t]{2}{*}{ Specification } & \multicolumn{2}{|c|}{ (1) } & \multicolumn{2}{|c|}{ (2) } & \multicolumn{2}{|c|}{ (3) } & \multicolumn{2}{|c|}{ (4) } \\
\hline & Estimate & $\begin{array}{l}\text { Odds } \\
\text { Ratio }\end{array}$ & Estimate & $\begin{array}{l}\text { Odds } \\
\text { Ratio }\end{array}$ & Estimate & $\begin{array}{l}\text { Odds } \\
\text { Ratio }\end{array}$ & Estimate & $\begin{array}{l}\text { Odds } \\
\text { Ratio }\end{array}$ \\
\hline Old Index ${ }^{\mathrm{A}}$ & $\begin{array}{l}0.01 \\
(0.01)\end{array}$ & 1.01 & & & & & & \\
\hline New Index ${ }^{A}$ & $\begin{array}{l}0.00 \\
(0.00)\end{array}$ & 1.00 & & & & & & \\
\hline Old Index ${ }^{\mathrm{M}}$ & & & $\begin{array}{l}0.00 \\
(0.00)\end{array}$ & 1.00 & & & & \\
\hline New Index ${ }^{\mathrm{M}}$ & & & $\begin{array}{l}-0.01 * * \\
(0.00)\end{array}$ & 0.99 & & & & \\
\hline $\begin{array}{l}\text { Combined } \\
\text { restrictions }\end{array}$ & & & & & $\begin{array}{l}-0.04 * \\
(0.01)\end{array}$ & 0.96 & & \\
\hline $\begin{array}{l}\text { Combined } \\
\text { coverage }\end{array}$ & & & & & $\begin{array}{l}0.04 * * \\
(0.01)\end{array}$ & 1.04 & & \\
\hline $\begin{array}{l}\text { Combined } \\
\text { enforcement }\end{array}$ & & & & & $\begin{array}{l}0.01 \\
(0.02) \\
\end{array}$ & 1.01 & & \\
\hline Old restrictions & & & & & & & $\begin{array}{l}-0.01 \\
(0.02)\end{array}$ & 0.99 \\
\hline Old coverage & & & & & & & $\begin{array}{l}0.00 \\
(0.03)\end{array}$ & 1.00 \\
\hline Old enforcement & & & & & & & $\begin{array}{l}0.05 \\
(0.03)\end{array}$ & 1.05 \\
\hline New restrictions & & & & & & & $\begin{array}{l}-0.05^{*} \\
(0.02)\end{array}$ & 0.95 \\
\hline New coverage & & & & & & & $\begin{array}{l}0.04 * * \\
(0.01)\end{array}$ & 1.04 \\
\hline New enforcement & & & & & & & $\begin{array}{l}-0.01 \\
(0.02)\end{array}$ & 0.99 \\
\hline
\end{tabular}

NOTE: Standard errors are in parentheses. * Significance at 5\% level. ** Significance at the

$1 \%$ level. The unit of change when evaluating the odds ratio is one. 
B. 2004 Originations, HMDA Price Definition of Subprime

\begin{tabular}{|c|c|c|c|c|c|c|c|c|}
\hline \multirow[t]{2}{*}{ Specification } & \multicolumn{2}{|c|}{$(1)$} & \multicolumn{2}{|c|}{ (2) } & \multicolumn{2}{|c|}{ (3) } & \multicolumn{2}{|c|}{ (4) } \\
\hline & Estimate & $\begin{array}{l}\text { Odds } \\
\text { Ratio } \\
\end{array}$ & Estimate & $\begin{array}{l}\text { Odds } \\
\text { Ratio } \\
\end{array}$ & Estimate & $\begin{array}{l}\text { Odds } \\
\text { Ratio } \\
\end{array}$ & Estimate & $\begin{array}{l}\text { Odds } \\
\text { Ratio } \\
\end{array}$ \\
\hline Old Index ${ }^{A}$ & $\begin{array}{l}0.02 * * \\
(0.01)\end{array}$ & 1.02 & & & & & & \\
\hline New Index ${ }^{\mathrm{A}}$ & $\begin{array}{l}0.00^{*} \\
(0.00)\end{array}$ & 1.00 & & & & & & \\
\hline Old Index ${ }^{M}$ & & & $\begin{array}{l}0.01 * * \\
(0.00)\end{array}$ & 1.01 & & & & \\
\hline New Index ${ }^{\mathrm{M}}$ & & & $\begin{array}{l}0.00 \\
(0.00)\end{array}$ & 1.00 & & & & \\
\hline $\begin{array}{l}\text { Combined } \\
\text { restrictions }\end{array}$ & & & & & $\begin{array}{l}0.04 * * \\
(0.01)\end{array}$ & 1.04 & & \\
\hline $\begin{array}{l}\text { Combined } \\
\text { coverage }\end{array}$ & & & & & $\begin{array}{l}0.00 \\
(0.00)\end{array}$ & 1.00 & & \\
\hline $\begin{array}{l}\text { Combined } \\
\text { enforcement }\end{array}$ & & & & & $\begin{array}{l}-0.02 \\
(0.02)\end{array}$ & 0.98 & & \\
\hline Old restrictions & & & & & & & $\begin{array}{l}0.05 * * \\
(0.02)\end{array}$ & 1.05 \\
\hline Old coverage & & & & & & & $\begin{array}{l}-0.02 \\
(0.03)\end{array}$ & 0.98 \\
\hline Old enforcement & & & & & & & $\begin{array}{l}0.03 \\
(0.02)\end{array}$ & 1.03 \\
\hline New restrictions & & & & & & & $\begin{array}{l}0.06 * * \\
(0.02)\end{array}$ & 1.06 \\
\hline New coverage & & & & & & & $\begin{array}{l}0.00 \\
(0.01)\end{array}$ & 1.00 \\
\hline New enforcement & & & & & & & $\begin{array}{l}-0.07 * * \\
(0.02)\end{array}$ & 0.93 \\
\hline
\end{tabular}

NOTE: Standard errors are in parentheses. * Significance at $5 \%$ level. ** Significance at the $1 \%$ level. The unit of change when evaluating the odds ratio is one. 
C. 2005 Originations, HMDA Price List Definition of Subprime

\begin{tabular}{|c|c|c|c|c|c|c|c|c|}
\hline \multirow[t]{2}{*}{ Specification } & \multicolumn{2}{|c|}{ (1) } & \multicolumn{2}{|c|}{$(2)$} & \multicolumn{2}{|c|}{ (3) } & \multicolumn{2}{|c|}{ (4) } \\
\hline & Estimate & $\begin{array}{l}\text { Odds } \\
\text { Ratio } \\
\end{array}$ & Estimate & $\begin{array}{l}\text { Odds } \\
\text { Ratio } \\
\end{array}$ & Estimate & $\begin{array}{l}\text { Odds } \\
\text { Ratio } \\
\end{array}$ & Estimate & $\begin{array}{l}\text { Odds } \\
\text { Ratio } \\
\end{array}$ \\
\hline Old Index ${ }^{A}$ & $\begin{array}{l}0.02 * * \\
(0.00)\end{array}$ & 1.02 & & & & & & \\
\hline New Index ${ }^{A}$ & $\begin{array}{l}0.00 \\
(0.00)\end{array}$ & 1.00 & & & & & & \\
\hline Old Index ${ }^{M}$ & & & $\begin{array}{l}0.01 * * \\
(0.00)\end{array}$ & 1.01 & & & & \\
\hline New Index ${ }^{M}$ & & & $\begin{array}{l}0.00 \\
(0.00)\end{array}$ & 1.00 & & & & \\
\hline $\begin{array}{l}\text { Combined } \\
\text { restrictions }\end{array}$ & & & & & $\begin{array}{l}-0.02 * \\
(0.01)\end{array}$ & 0.98 & & \\
\hline $\begin{array}{l}\text { Combined } \\
\text { coverage }\end{array}$ & & & & & $\begin{array}{l}0.03 * * \\
(0.01)\end{array}$ & 1.03 & & \\
\hline $\begin{array}{l}\text { Combined } \\
\text { enforcement }\end{array}$ & & & & & $\begin{array}{l}0.03 * \\
(0.01)\end{array}$ & 1.03 & & \\
\hline Old restrictions & & & & & & & $\begin{array}{l}0.00 \\
(0.01)\end{array}$ & 1.00 \\
\hline Old coverage & & & & & & & $\begin{array}{l}0.03 \\
(0.02) \\
\end{array}$ & 1.03 \\
\hline Old enforcement & & & & & & & $\begin{array}{l}0.03^{*} \\
(0.02)\end{array}$ & 1.03 \\
\hline New restrictions & & & & & & & $\begin{array}{l}-0.05^{*} \\
(0.02)\end{array}$ & 0.95 \\
\hline New coverage & & & & & & & $\begin{array}{l}0.03 * * \\
(0.01)\end{array}$ & 1.03 \\
\hline New enforcement & & & & & & & $\begin{array}{l}0.02 \\
(0.02)\end{array}$ & 1.02 \\
\hline
\end{tabular}

NOTE: Standard errors are in parentheses. * Significance at $5 \%$ level. ** Significance at the $1 \%$ level. The unit of change when evaluating the odds ratio is one. 
D. 2004 Applications, HUD List Definition of Subprime

\begin{tabular}{|c|c|c|c|c|c|c|c|c|}
\hline \multirow[t]{2}{*}{ Specification } & \multicolumn{2}{|c|}{ (1) } & \multicolumn{2}{|c|}{ (2) } & \multicolumn{2}{|c|}{ (3) } & \multicolumn{2}{|c|}{ (4) } \\
\hline & Estimate & $\begin{array}{l}\text { Odds } \\
\text { Ratio }\end{array}$ & Estimate & $\begin{array}{l}\text { Odds } \\
\text { Ratio }\end{array}$ & Estimate & $\begin{array}{l}\text { Odds } \\
\text { Ratio }\end{array}$ & Estimate & $\begin{array}{l}\text { Odds } \\
\text { Ratio }\end{array}$ \\
\hline Old Index ${ }^{A}$ & $\begin{array}{l}0.00 \\
(0.00)\end{array}$ & 1.00 & & & & & & \\
\hline New Index ${ }^{A}$ & $\begin{array}{l}-0.01 * * \\
(0.00)\end{array}$ & 0.99 & & & & & & \\
\hline Old Index $^{\mathrm{M}}$ & & & $\begin{array}{l}0.00 \\
(0.00)\end{array}$ & 1.00 & & & & \\
\hline New Index ${ }^{\mathrm{M}}$ & & & $\begin{array}{l}-0.01 * * \\
(0.00)\end{array}$ & 0.99 & & & & \\
\hline $\begin{array}{l}\text { Combined } \\
\text { restrictions }\end{array}$ & & & & & $\begin{array}{l}0.01 \\
(0.01)\end{array}$ & 1.01 & & \\
\hline $\begin{array}{l}\text { Combined } \\
\text { coverage }\end{array}$ & & & & & $\begin{array}{l}-0.02 * * \\
(0.01)\end{array}$ & 0.98 & & \\
\hline $\begin{array}{l}\text { Combined } \\
\text { enforcement }\end{array}$ & & & & & $\begin{array}{l}0.00 \\
(0.01)\end{array}$ & 1.00 & & \\
\hline Old restrictions & & & & & & & $\begin{array}{l}0.03 * \\
(0.01)\end{array}$ & 1.03 \\
\hline Old coverage & & & & & & & $\begin{array}{l}-0.11 * * \\
(0.03)\end{array}$ & 0.90 \\
\hline Old enforcement & & & & & & & $\begin{array}{l}0.06 * * \\
(0.02)\end{array}$ & 1.06 \\
\hline New restrictions & & & & & & & $\begin{array}{l}0.03 \\
(0.02)\end{array}$ & 1.03 \\
\hline New coverage & & & & & & & $\begin{array}{l}-0.02 * * \\
(0.01)\end{array}$ & 0.98 \\
\hline New enforcement & & & & & & & $\begin{array}{l}-0.05 * * \\
(0.02)\end{array}$ & 0.95 \\
\hline
\end{tabular}

NOTE: Standard errors are in parentheses. * Significance at 5\% level. ** Significance at the $1 \%$ level. The unit of change when evaluating the odds ratio is one. 
E. 2004 Rejection rates, HUD List Definition of Subprime

\begin{tabular}{|c|c|c|c|c|c|c|c|c|}
\hline Specification & \multicolumn{2}{|c|}{ (1) } & \multicolumn{2}{|c|}{$(2)$} & \multicolumn{2}{|c|}{ (3) } & \multicolumn{2}{|c|}{ (4) } \\
\hline & Estimate & $\begin{array}{l}\text { Odds } \\
\text { Ratio } \\
\end{array}$ & Estimate & $\begin{array}{l}\text { Odds } \\
\text { Ratio } \\
\end{array}$ & Estimate & $\begin{array}{l}\text { Odds } \\
\text { Ratio } \\
\end{array}$ & Estimate & $\begin{array}{l}\text { Odds } \\
\text { Ratio } \\
\end{array}$ \\
\hline Old Index ${ }^{A}$ & $\begin{array}{l}-0.01^{* *} \\
(0.00)\end{array}$ & 0.99 & & & & & & \\
\hline New Index ${ }^{A}$ & $\begin{array}{l}0.00 \\
(0.00)\end{array}$ & 1.00 & & & & & & \\
\hline Old Index ${ }^{M}$ & & & $\begin{array}{l}-0.01 * * \\
(0.00)\end{array}$ & 0.99 & & & & \\
\hline New Index ${ }^{M}$ & & & $\begin{array}{l}0.00 * * \\
(0.00)\end{array}$ & 1.00 & & & & \\
\hline $\begin{array}{l}\text { Combined } \\
\text { restrictions }\end{array}$ & & & & & $\begin{array}{l}0.08 * * \\
(0.01)\end{array}$ & 1.08 & & \\
\hline $\begin{array}{l}\text { Combined } \\
\text { coverage }\end{array}$ & & & & & $\begin{array}{l}-0.08^{* *} \\
(0.01)\end{array}$ & 0.92 & & \\
\hline $\begin{array}{l}\text { Combined } \\
\text { enforcement }\end{array}$ & & & & & $\begin{array}{l}-0.03^{* *} \\
(0.01) \\
\end{array}$ & 0.97 & & \\
\hline Old restrictions & & & & & & & $\begin{array}{l}0.04 * * \\
(0.01)\end{array}$ & 1.04 \\
\hline Old coverage & & & & & & & $\begin{array}{l}-0.08^{* *} \\
(0.02) \\
\end{array}$ & 0.93 \\
\hline Old enforcement & & & & & & & $\begin{array}{l}-0.03 \\
(0.02)\end{array}$ & 0.97 \\
\hline New restrictions & & & & & & & $\begin{array}{l}0.13 * * \\
(0.02) \\
\end{array}$ & 1.14 \\
\hline New coverage & & & & & & & $\begin{array}{l}-0.08^{* *} \\
(0.01) \\
\end{array}$ & 0.92 \\
\hline New enforcement & & & & & & & $\begin{array}{l}-0.04^{*} \\
(0.02)\end{array}$ & 0.96 \\
\hline
\end{tabular}

NOTE: Standard errors are in parentheses. * Significance at 5\% level. ** Significance at the $1 \%$ level.

The unit of change when evaluating the odds ratio is one 


\footnotetext{
${ }^{1}$ The subprime market is designed for borrowers with unconventional or blemished credit histories and charges higher interest rates and fees.
}

${ }^{2}$ In 1998, subprime mortgages comprised $2.4 \%$ of outstanding home mortgage loans; by the second quarter of 2006, they made up 13.4\%. Duncan (2006).

${ }^{3}$ While predatory lending is hard to define with precision, it generally either involves excessive prices in view of the borrowers' risk or lending without regard to borrowers' ability to repay. Engel and McCoy (2006) define predatory lending as a syndrome of loan terms or practices involving one or more of the following features: (1) loans structured to result in seriously disproportionate net harm to borrowers; (2) rent-seeking; (3) illegal fraud or deception; (4) other information asymmetries favoring brokers or lenders; (5) mandatory arbitration clauses; (6) lending discrimination; and (7) servicing abuses.

${ }^{4}$ On a parallel front, federal, state and local authorities have brought civil and criminal claims against numerous subprime mortgage lenders and brokers for violations of lending laws, see e.g. Engel \& McCoy (2007).

${ }^{5}$ Azmy (2005).

${ }^{6}$ For discussion of negative externalities from abusive mortgage lending, see, e.g., Apgar \& Duda (2005), Engel (2006), and Quercia, Cowan \& Moreno (2005).

${ }^{7}$ For the year ending December 30, 2006, delinquencies stood at 13.3 percent for subprime loans generally and 14.4 percent for subprime adjustable-rate mortgages. Mortgage Bankers Association (2007).

${ }^{8}$ Peterson (2004).

${ }^{9}$ Eskridge (1984); Whitman (1992). Colorado, Idaho, Indiana, Iowa, Kansas, Maine, Oklahoma, South Carolina, Utah, Wisconsin, and Wyoming adopted the Uniform Consumer Credit Code. Legal Information Institute (2007). Not all states' versions of the U.C.C.C., however, regulate prepayment clauses or balloon clauses.

${ }^{10} 15$ U.S.C. $\S 1602(a a)(1)-(4) ; 12$ C.F.R. $§ 226.32(a)(1)$, (b)(1). For 2007, the dollar trigger was raised to $\$ 547.71$ Fed. Reg. 46388 (Aug. 14, 2006). HOEPA contains a complex system of exclusions from "total points and fees." The exclusions include certain application fees, late charges, closing costs, securityinterest charges, and filing and recording fees. National Consumer Law Center § 3.9 (1999).

${ }^{11}$ Federal Reserve System (2001), at 65,606-65,610.

${ }^{12}$ Loan flipping involves refinancing a residential mortgage with high fees in order to strip equity from a home, with little or no benefit to the borrower. When loan flipping occurs, often it is instigated by the original lender, mortgage broker, or one of their affiliates.

${ }^{13} 12$ C.F.R. $\S \S 226.32,226.34$. In general, holders of HOEPA loans "are subject to all claims and defenses .. . that could be raised against the original lender." 15 U.S.C. $\$ 1641(\mathrm{~d})(1)$.

${ }^{14}$ Demyanyk (2006) has surmised that states with comparatively high-income inequality are more likely to pass mini-HOEPA statutes. According to her estimates, every 10 percent increase in income inequality in a 
state in the current period made it 8 percent more likely that a state would adopt a predatory lending law in the next period.

When legislative campaigns stalled at the state level, some cities and counties passed antipredatory lending ordinances of their own. These include Atlanta, Chicago, Cleveland, Cleveland Heights, Cook County (IL), Dayton, DeKalb County (IL), Detroit, Los Angeles, New York City, Oakland, Philadelphia, and Toledo. All of these ordinances have been enjoined by court order, preempted by state legislation, or limited in coverage to lenders who contract with the cities. In most cases, these ordinances never took effect or if they did take effect, they did so only briefly.

${ }^{15}$ Renuart \& Keest (2005), §§ 3.10.1, 3.10.2 at n. 679; see infra note 23.

${ }^{16} 12$ C.F.R. § 560.2; Renuart \& Keest (2005), § 3.5.3.

${ }^{17} 69$ Fed. Reg. 1904 (Jan. 13, 2004) (codified at 12 C.F.R. $\$ \S 34.3$, 34.4). In the years preceding this regulation, the O.C.C. issued several preemption rulings applying to discrete laws in individual states. In the most famous of these rulings, issued in 2003, the O.C.C. preempted the Georgia Fair Lending Act. Renuart \& Keest (2005), § 3.4.6.1.

${ }^{18}$ See, e.g., O.C.G.A. §7-6A-12; Johnson (1995).

${ }^{19}$ The article did not explain how subprime loans were defined. The American Financial Services Association represents large subprime lenders. At the time of the study, its members included Ameriquest Mortgage Company, Conseco Financial Corporation, Countrywide Home Loans, Equity One, CitiFinancial, Household Finance Corporation, Key Consumer Real Estate, Washington Mutual Finance, and Wells Fargo Financial, Inc.

${ }^{20}$ The study only compared subprime lending before and after the law's enactment date, rather than before enactment and after the full effective date. Although the authors conceded that that "window for detecting changes in lending patterns following passage of the North Carolina statute [was] narrow," they argued that "creditors would not wait for the law to be fully effective to adjust their operations" because some parts of the law (including the ban on prepayment penalties) became effective in part on October 1, 1999 and even those provisions that did not go into effect until June 1, 2000 were known by July 1999, when the law was passed. Id. at 422 .

${ }^{21}$ From 1982 through year-end 2003, South Carolina banned prepayment penalties in most personal mortgages of up to $\$ 100,000$. Former S.C. Code Ann. § 37-10-103 (2001). Another control state, Virginia, had a similar ban. Starting in 1987 and continuing today, Virginia limited the size of prepayment penalties in junior lien residential mortgages. The state later banned prepayment penalties altogether in refinancings of those mortgages by the same lender or an assignee. Va. Stat. $\S \S 6.1-330.83 \& 6.1-330.85$ (2006). Meanwhile, Tennessee's usury law required disclosure of certain prepayment penalties in residential mortgages as of January 1, 2001. Tenn. Code Ann. § 47-14-108 (2006).

Until July 2003, the federal Alternative Mortgage Transaction Parity Act (AMTPA) preempted state restrictions on prepayment penalty and balloon clauses for mortgages other than fixed-rate, fully amortizing mortgages made by "state housing creditors" (i.e., non-depository lenders). AMTPA preemption applied in all states except six states that timely opted out of AMTPA's coverage. Renuart \& Keest (2005), $\S \S 3.10 .1,3.10 .2$. In July 2003, the U.S. Office of Thrift Supervision (2003) issued a ruling reversing federal preemption of state prepayment penalty laws under AMTPA. The ruling thus revived state laws regulating prepayment penalties for non-depository finance companies.

${ }^{22}$ For comment on this study, see Center for Responsible Lending (2004).

${ }^{23}$ Scheessele (1999); HUD Subprime and Manufactured Home Lender List (2007). 
${ }^{24}$ Defined as a prepayment penalty of more than three years, a balloon payment, and/or a combined loanto-value ratio of 100 percent or more. For debate of an earlier draft of this study, see U.S. Office of the Comptroller of the Currency (2003), Litan (2003) and Stegman, Quercia \& Davis (2003).

25 Quercia, Stegman \& Davis (2004) at 596.

${ }^{26}$ The Philadelphia ordinance took effect on April 19, 2001. Philadelphia Municipal Ordinance 00-715A (2000). The Pennsylvania legislature preempted the city ordinance effective June 25, 2001. $63 \mathrm{~Pa}$. Stat. 456.504. The study mistakenly used October 1, 2001 through March 31, 2002 as the period in which the Philadelphia was in effect. By then, however, the law had already been overturned.

${ }^{27}$ Another report, by the Center for Statistical Research (2003), estimated that enactment of a law would cause subprime mortgage loans to decrease in New Jersey, based on data from North Carolina after passage of the North Carolina law. The study used rudimentary methodology and studied a time-period that ended twenty months before the New Jersey law was passed.

${ }^{28}$ Morgan Stanley (2002) at 11.

${ }^{29}$ In Georgia (but not New Jersey), the reduction in overall subprime originations was attributable to a decline in loans with predatory features. Li \& Ernst (2006) at 13-14.

${ }^{30}$ Compared with the control states, nominal interest rates rose an average of 15.4 basis points on fixed-rate 30 -year subprime mortgages without prepayment penalties in Georgia and rose 17.3 basis points on average on adjustable-rate $2 / 28$ hybrid mortgages without prepayment penalties in Virginia. Id. at 16-17. It is possible that the Georgia wild card statute (see note 19 supra) helps explain the Georgia results.

${ }^{31}$ The sample included border counties in ten states with anti-predatory lending laws - California, Connecticut, Florida, Georgia, Maryland, Massachusetts, North Carolina, Ohio, Pennsylvania, and Texas and border counties in adjacent, unregulated states as controls. Ho and Pennington-Cross (2006b) at 218.

${ }^{32}$ After doing our own legal research, we recalculated the 22 individual state rankings based on the coverage and restrictions indexes in this paper. Arkansas, California, Colorado, Connecticut, , Maryland, Massachusetts, North Carolina, New Mexico, Okalahoma, South Carolina, and Utah had the strongest combined rankings for coverage and restrictions of the 22 states.

${ }^{33}$ Prior research has typically relied on summaries of state and local anti-predatory lending laws compiled by law firms and trade associations.

${ }^{34}$ Standard \& Poor's (2005).

${ }^{35}$ As of January $5^{\text {th }}, 2007$ the list was only available for 2004 HMDA. This list is a lender list so loans identified as subprime are likely to also include some prime loans and loans identified as prime are likely to include some subprime loans.

${ }^{36}$ Therefore the average for Index ${ }^{\mathrm{A}}$ is 3 by design, and the average for Index ${ }^{\mathrm{M}}$ will deviate slightly depending on the distribution of scores. In addition, relative to index ${ }^{\mathrm{A}}$, the standard deviation of the index ${ }^{\mathrm{M}}$ will be larger.

${ }^{37}$ This is done because HMDA reports data annually with no other more detailed date information. As a result, the 2004 sample will only include loans that were in effect before January 2004 and the 2005 sample will only include laws that were in effect before January 2005.

${ }^{38}$ State homestead exclusions are another legal consideration that could conceivably influence subprime market outcomes. However, those exclusions do not generally apply to efforts of creditors to enforce 
home-secured mortgages, either by their express terms or as interpreted by the courts. Lloyd (1985). Consequently they are not included in this analysis.

${ }^{39}$ Elliehausen and Staten (2004, 2006), Harvey and Nigro (2003, 2004), Li and Ernst (2006) and Ho \& Pennington-Cross (2006a, 2006b) all use borrower and location controls.

${ }^{40}$ The logit specification is given by $\operatorname{Pr}(Y=1)=e^{x_{i} \beta} /\left(1+e^{x_{i} \beta}\right)$, where $Y$ is the outcome (application, origination, or rejection), $x$ is a vector of explanatory variables as defined in the specification, and $\beta$ is a vector of parameters to be estimated.

${ }^{41}$ Federal Financial Institutions Examination Council (2004), Board of Governors of the Federal Reserve System (2004). 